Supporting Information

\title{
Enhanced electrocatalytic activity of nickel cobalt phosphide nanoparticles anchored on porous N-doped fullerene nanorod for efficient overall water splitting
}

Yongqiang Feng, ${ }^{\dagger, \|, *}$ Ran Wang,,,$\|$ Peipei Dong, ${ }^{\dagger}$ Xiao Wang, ${ }^{\dagger}$ Weihang Feng, ${ }^{\dagger}$

Junsheng Chen,${ }^{\dagger}$ Liyun Cao,${ }^{\dagger}$ Liangliang Feng, ${ }^{\dagger}$ Chaozheng He,,${ }^{\ddagger} *$ Jianfeng Huang,${ }^{\dagger}$

${ }^{\dagger}$ School of Materials Science and Engineering, Shaanxi Key Laboratory of Green

Preparation and Functionalization for Inorganic Materials, Key Laboratory of

Auxiliary Chemistry and Technology for Chemical Industry, Ministry of Education,

Shaanxi University of Science and Technology, Xi' an 710021, China

\#Institute of Environmental and Energy Catalysis, Shaanxi Key Laboratory of

Optoelectronic Functional Materials and Devices, School of Materials Science and

Chemical Engineering, Xi' an Technological University, Xi'an 710021, People’s

Republic of China

॥ These authors contribute equally.

\section{Corresponding Authors}

*E-mail: fengyq@sust.edu.cn (Y.Q.F.)

*E-mail: hecz2019@xatu.edu.cn (C.Z.H.) 


\section{Contents}

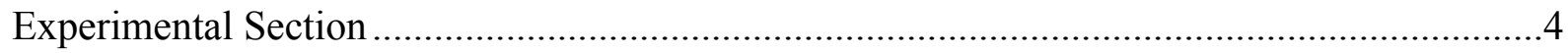

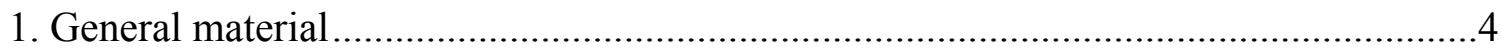

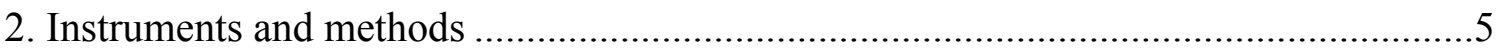

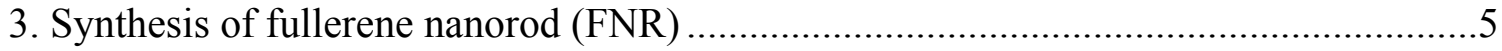

Figure S1. SEM images of fullerene nanostructures prepared using $\mathrm{MeOH}$ (a), EtOH (b) and IPA (c) as the anti-solvent, respectively, and the corresponding

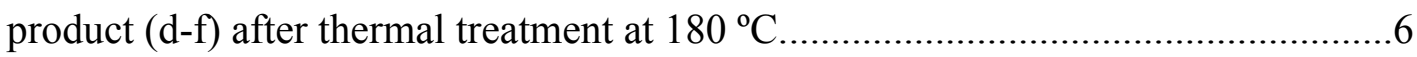

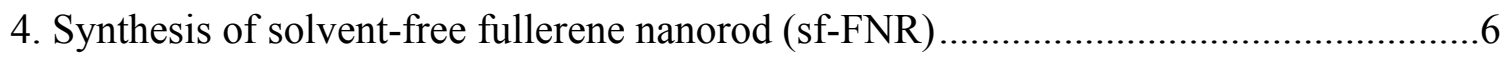

Figure S2. TGA profiles of FNR (black), sf-FNR (red) and sf-FNR/PVP (blue)......7

5. Synthesis of sf-FNR/PVP 7

Figure S3. Contact angle of (a) FNR, (b) sf-FNR and (c) sf-FNR/PVP ..................7

Figure S4. Raman spectra of sf-FNR/PVP (red), sf-FNR (purple), FNR (blue) and

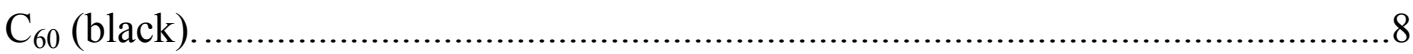

Figure S5. FTIR spectra of sf-FNR/PVP (red), sf-FNR (purple), FNR (blue) and $\mathrm{C}_{60}$ (black) .8

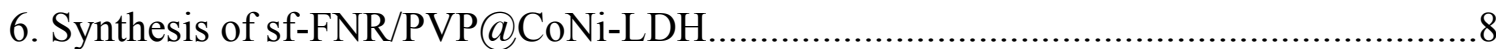

Figure S6. XRD pattern of sf-FNR/PVP@CoNi-LDH.......................................

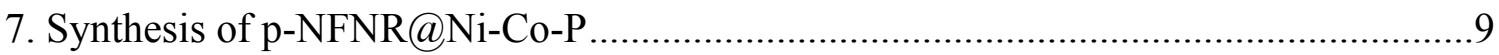

Figure S7. (a-c) TEM images of p-NFNR@Ni-Co-P showing the nanoparticles decorated on the porous surface of $\mathrm{p}-\mathrm{NFNR}$ 10

Figure S8. (a) SEM and (b) TEM image of Ni-Co-P 10 
Figure S9. Nitrogen adsorption (solid circle) and desorption (empty circle) of pNFNR@Ni-Co-P (red), sf-FNR (purple) and FNR (blue).

Figure S10. XPS profiles of P 2p for p-NFNR@Ni-Co-P (a), P 2p (b), Ni 2p (c) and Co $2 p(d)$ for Ni-Co-P.

8. Electrochemical measurements

Figure S11. LSV curves of p-NFNR@Ni-Co-P prepared by using different mass loading of sf-FNR/PVP under a scan rate of $5 \mathrm{mV} \mathrm{s}^{-1}$ in $1 \mathrm{M} \mathrm{KOH}$.

Figure S12. LSV curves of p-NFNR@Ni-Co-P prepared by using different mass loading of sf-FNR/PVP under a scan rate of $5 \mathrm{mV} \mathrm{s}^{-1}$ in $1 \mathrm{M} \mathrm{KOH}$.

Figure S13. Polarization plots of HER (a) and OER (b) for p-NFNR@Ni-Co-P (red), p-NFNR@Ni ${ }_{2} \mathrm{P}$ (dark green), p-NFNR@CoP (orange), Ni-Co-P (black), 20 wt.\% Pt/C and $\mathrm{IrO}_{2}$ (blue), sf-FNR/PVP/CoNi-LDH (pink), CoNi-LDH (cyan), sfFNR (purple) and FNR (light green), respectively.

Figure S14. CV curves of (a) p-NFNR@Ni-Co-P and (b) Ni-Co-P with different scanning rate from 20 to $120 \mathrm{mV} \mathrm{s}^{-1}$ in the range of $0.05-0.15 \mathrm{~V}$ in $1 \mathrm{M} \mathrm{KOH}$ for HER

Figure S15. CV curves of (a) p-NFNR@Ni-Co-P and (b) Ni-Co-P with different scanning rate from 20 to $120 \mathrm{mV} \mathrm{s}^{-1}$ in the range of $0.05-0.15 \mathrm{~V}$ in $1 \mathrm{M} \mathrm{KOH}$ for OER

Figure S16. XRD patterns of (a) p-NFNR@Ni $2 \mathrm{P}$ and (b) p-NFNR@CoP.

Figure S17. Polarization plots of HER (a) and OER (b) for p-NFNR@Ni-Co-P (1:1) (red), p-NFNR@Ni-Co-P (2:1) (dark blue), p-NFNR@Ni-Co-P (1:2) (light blue) with the samples with different $\mathrm{Ni} / \mathrm{Co}$ ratio.

Figure S18. Polarization plots of HER (a) and OER (b) for p-NFNR@Ni-Co-P (PVP-1) (red), p-NFNR@Ni-Co-P (PVP-0.5) (blue), p-NFNR@Ni-Co-P (PVP-1.5) (black) with the samples with different addition amount of PVP..... 
Figure S19. XRD patterns of p-NFNR@Ni-Co-P after OER test.

Figure S20. (a) Typical TEM image and (b) HRTEM image of p-NFNR@Ni-Co-P after long-term $I$-t test for OER measurement.

Figure S21. XPS profiles of p-NFNR@Ni-Co-P after OER test. (a) Ni 2p, (b) Co

$2 \mathrm{p}$, (c) P $2 \mathrm{p}$ and (d) N 1s.

Figure S22. XRD patterns of p-NFNR@Ni-Co-P before (black) and after (red)

HER test. .20

Figure S23. (a) Typical TEM image and (b) HRTEM image of p-NFNR@Ni-Co-P after long-term $I$-t test for HER measurement .20

Theoretical Section:

Figure S24. The structures of $\mathrm{NiCoP} / \mathrm{F}$ and $\mathrm{NiCoP}$.

Figure S25. Charge differential density of the most stable adsorption configurations of $\mathrm{OH}^{*}, \mathrm{O}^{*}$, and $\mathrm{OOH}^{*}$ on $\mathrm{NiCoP} / \mathrm{F}$ (a) and $\mathrm{NiCoP}(\mathrm{b})$. The iso-surface value of charge differential density is $0.05 \mathrm{e} / \AA^{3}$, blue and yellow represent charge depletion and accumulation. "*" means the chemical adsorption.

Table S1. The ICP and XPS results of atomic ratio (\%) of Ni, Co, P and $\mathrm{N}$ for the optimal sample of p-NFNR@Ni-Co-P.

Table S2. The HER properties of p-NFNR@Ni-Co-P compared with other nonprecious metal-based OER catalysts in $1 \mathrm{M} \mathrm{KOH}$

Table S3. The OER properties of p-NFNR@Ni-Co-P compared with other nonprecious metal-based HER catalysts in $1 \mathrm{M} \mathrm{KOH}$

Table S4. The overall water splitting properties of p-NFNR@Ni-Co-P compared with other non-precious metal-based overall water splitting catalysts in $1 \mathrm{M} \mathrm{KOH}$.

Table S5. The Ni, Co, P and N content and electronic conductivity $(\sigma)$ in the sample of p-NFNR@Ni-Co-P with different addition amount of PVP. .26 


\section{Experimental Section}

\section{General material}

Fullerene $\mathrm{C}_{60}$ was received from Xiamen Funano New Material Technology Co., Ltd, nickel(II) nitrate hexahydrate $\left(\mathrm{Ni}\left(\mathrm{NO}_{3}\right)_{2} \cdot 6 \mathrm{H}_{2} \mathrm{O}, \geq 98 \%\right)$, cobalt nitrate hexahydrate $\left(\mathrm{Co}\left(\mathrm{NO}_{3}\right)_{2} \cdot 6 \mathrm{H}_{2} \mathrm{O}, \geq 99 \%\right)$, urea $\left(\mathrm{CO}\left(\mathrm{NH}_{2}\right)_{2}, \geq 99 \%\right)$, methanol (MeOH, $\left.\mathrm{CH}_{3} \mathrm{OH}, 99 \%\right)$, ethanol

(EtOH, $\quad \mathrm{CH}_{3} \mathrm{CH}_{2} \mathrm{OH}, \quad 99.7 \%$ ), isopropanol (IPA, $\left.\quad \mathrm{CH}_{3} \mathrm{CH}(\mathrm{OH}) \mathrm{CH}_{3}, \quad 98 \%\right), \quad$ 1,3,5trimethylbenzene (TMB, $\left.\mathrm{C}_{9} \mathrm{H}_{12}, 98 \%\right)$, ethylene glycol $\left(\mathrm{EG}, \mathrm{CH}_{2}(\mathrm{OH}) \mathrm{CH}_{2} \mathrm{OH}, 98 \%\right)$ and sodium hypophosphite $\left(\mathrm{NaH}_{2} \mathrm{PO}_{2}, 98 \%\right)$ were purchased from Sinopharm Chemical Reagent Co., Ltd., polyvinyl pyrrolidone (PVP, $\left.\left(\mathrm{C}_{6} \mathrm{H}_{9} \mathrm{NO}\right)_{\mathrm{n}}, \mathrm{K} 30\right)$ was obtained from Energy Chemical Co., Ltd., potassium hydroxide $(\mathrm{KOH}, \geq 85 \%)$ were received from Kermel, and deionized (DI) water (resistivity: $18.3 \mathrm{M} \Omega \cdot \mathrm{cm}$ ) were produced by an ultrapure water system (ULUPURE, UPDR-I-10T). All the chemical reagents were used as received without further treatment.

\section{Instruments and methods}

Field-emission scanning electron microscopy (FE-SEM) was conducted on a JEOL S4800 instrument. Transmission electron microscopy (TEM) images and element mapping analysis were performed on a FEI Tecnai G2 F20 S-TWIN instrument. Raman spectrum was recorded on a Renishaw-invia instrument. Fourier transform infrared spectroscopy (FTIR) was exerted on a BrukerVector-22 machine. Powder X-ray diffraction (XRD) were carried out on a Rigaku D/max-2200PC diffractometer (Japan) with $\mathrm{Cu}$ Karadiation $(\lambda=0.15418 \mathrm{~nm})$. The thermogravimetry analysis (TGA) was performed on a SETARAM LABSYS machine (LABSYS EVO, France) for the weight loss measurement. X-ray photoelectron spectroscopy (XPS) spectra were performed on the Thermo Scientific ESCALab 250Xi using $200 \mathrm{~W}$ monochromated $\mathrm{Al} \mathrm{K} \alpha$ radiation. Nitrogen adsorption/desorption isotherm curves were recorded on a Quantachrome Autosorb AS-1 instrument at $77 \mathrm{~K}$. The conductivity was 
measured by four-point probe technique (BD-86A, China). Contact angle measurement was performed on Dataphyscs OCA20 instrument. Electrochemical measurements were conducted on the CHI660E (Chenhua, Shanghai) instrument.

\section{Synthesis of fullerene nanorod (FNR)}

FNR was synthesized via a modified liquid-liquid interfacial precipitation (LLIP) according to the previous literatures. ${ }^{1,2}$ Briefly, to a $100 \mathrm{~mL}$ round-bottom flask containing $50 \mathrm{~mL}$ of TMB, $50 \mathrm{mg}$ of fullerene $\mathrm{C}_{60}$ was added under vigorously stirring. After sonification for $30 \mathrm{~min}, 100$ $\mathrm{mL}$ of alcohol $(\mathrm{MeOH}, \mathrm{EtOH}$ or IPA) was added slowly into the purple solution. The mixture was stand for $12 \mathrm{~h}$ without disturbance. The product was centrifuged with a speed rate of 6000 r.p.m. for $30 \mathrm{~min}$ and then dried at $60^{\circ} \mathrm{C}$ for $12 \mathrm{~h}$.

As can be seen from Figure S1, the morphology of the as-synthesized FNR using IPA as the anti-solvent exhibited one-dimensional (1D) nanorod and it remained intact after thermal treatment, while for the products using $\mathrm{MeOH}$ and $\mathrm{EtOH}$ as poor solvent, it changed to large blocks after dispelling the TMB via heating at $180^{\circ} \mathrm{C}$. To take advantage of the electric current collector (ECC), the 1D FNR prepared by using IPA was selected as the matrix.
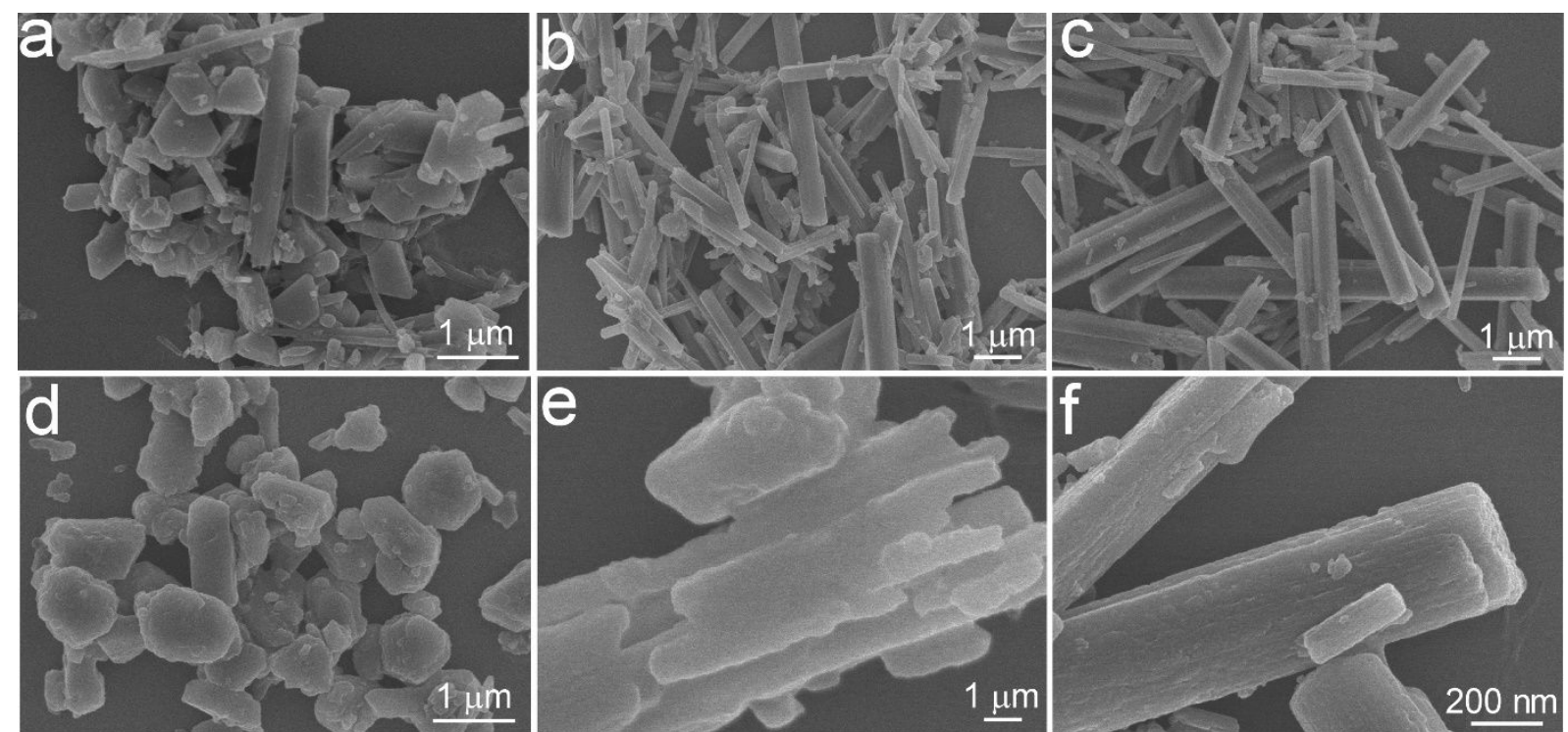

Figure S1. SEM images of fullerene nanostructures prepared using $\mathrm{MeOH}(\mathrm{a}), \mathrm{EtOH}(\mathrm{b})$ and IPA (c) as the anti-solvent, respectively, and the corresponding product (d-f) after thermal treatment at $180^{\circ} \mathrm{C}$. 


\section{Synthesis of solvent-free fullerene nanorod (sf-FNR)}

To dispel the TMB molecules co-crystalized within FNR, the as-obtained FNR was thermally heated at $180{ }^{\circ} \mathrm{C}$ according to the TGA curve shown in Figure S2. At around $160{ }^{\circ} \mathrm{C}$ the FNR displayed a weight loss which was ascribed to the loss of TMB solvent. Whereas for sf-FNR and sf-FNR/PVP, this peak was disappeared, indicating the solvent was completely dispelled out of FNR.

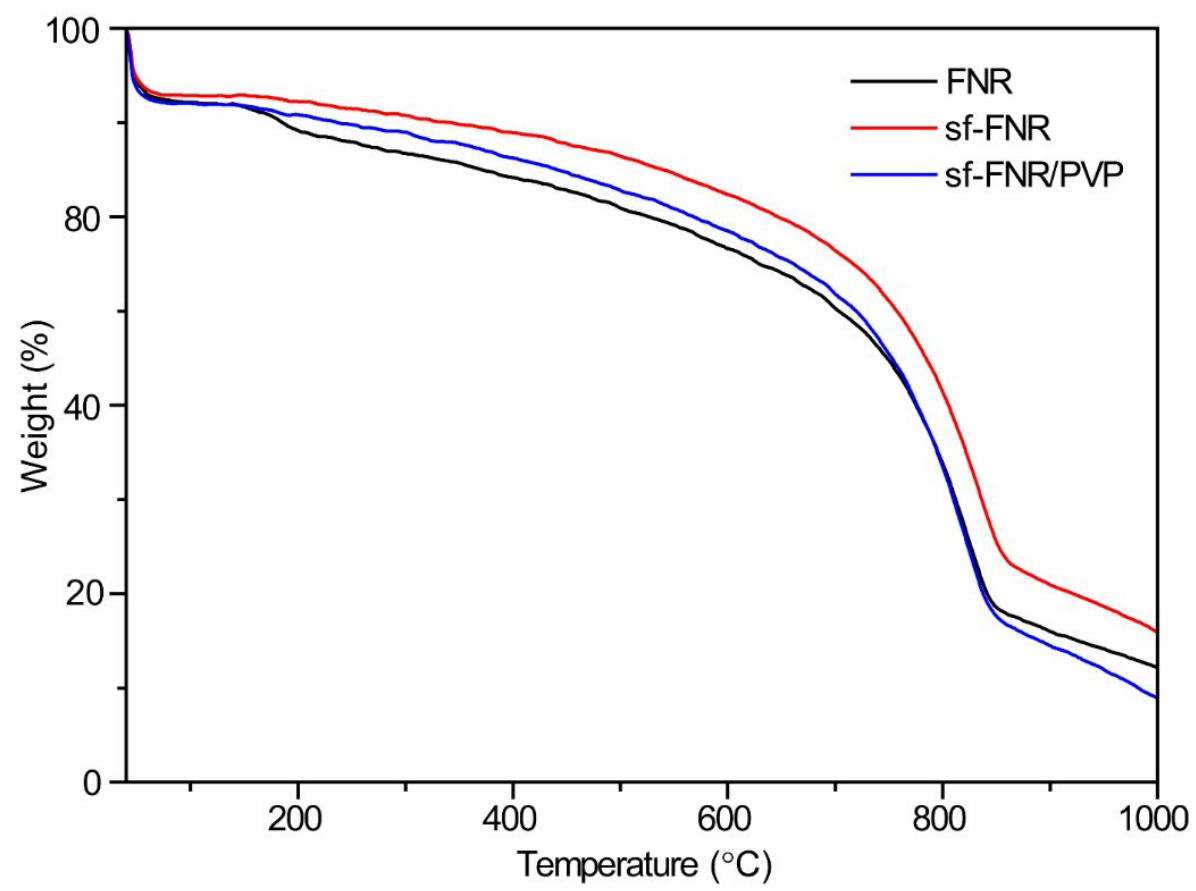

Figure S2. TGA profiles of FNR (black), sf-FNR (red) and sf-FNR/PVP (blue).

\section{Synthesis of sf-FNR/PVP}

To improve the hydrophilicity of the fullerene assembly, the obtained sf-FNR was covered by PVP polymer. Experimentally, $200 \mathrm{mg}$ of sf-FNR powder was added into the solution of 1 g PVP dissolved in $100 \mathrm{~mL}$ of DI water, after stirring for $10 \mathrm{~min}$, the mixture was reflux for 3 h. After cooling to room temperature, the product was separated by centrifuging at 8000 r.p.m. washed by $\mathrm{EtOH}$ and water repeatedly, and dried at $60{ }^{\circ} \mathrm{C}$ in vacuum for $12 \mathrm{~h}$. Fascinatingly, after the modification of PVP, the contact angle of sf-FNR/PVP was decreased from $145.47^{\circ}$ for the pristine FNR and $137.28^{\circ}$ for sf-FNR to only $16.28^{\circ}$ (Figure S3), indicating that the hydrophilic property of sf-FNR/PVP was favorable for water adsorption during the electrocatalytic reaction. 


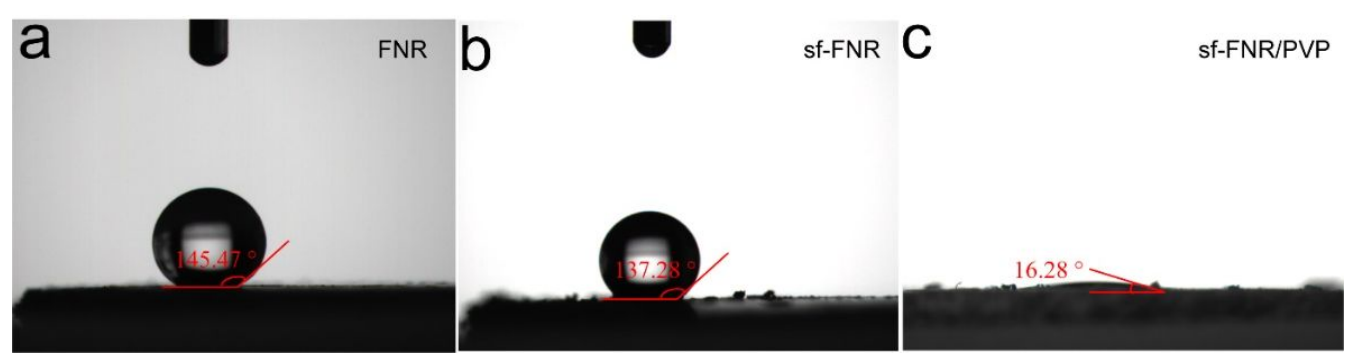

Figure S3. Contact angle of (a) FNR, (b) sf-FNR and (c) sf-FNR/PVP.

The structure of the newly-synthesized FNR, sf-FNR and sf-FNR/PVP together with the pristine $\mathrm{C}_{60}$ were further investigated by Raman and FTIR spectra as shown in Figure S4 and S5, respectively. The Rama spectra of $\mathrm{C}_{60}, \mathrm{FNR}$, sf-FNR and sf-FNR/PVP kept the same pattern with characteristic peaks at $269,491,1415,1455$ and $1570 \mathrm{~cm}^{-1}$. Notably, the vibration shift located at $1455 \mathrm{~cm}^{-1}$ implied the $\mathrm{C}_{60}$ molecules were covalently connected, which would facilitate the charge transfer process. ${ }^{3,4}$ In the FTIR spectra, the new peaks for FNR compared to $\mathrm{C}_{60}$ may be caused by self-assembly of the fullerene molecules. The change of the spectra for sf-FNR and sf-FNR/PVP between $790-880 \mathrm{~cm}^{-1}$ could be attributed to the introduce of PVP.

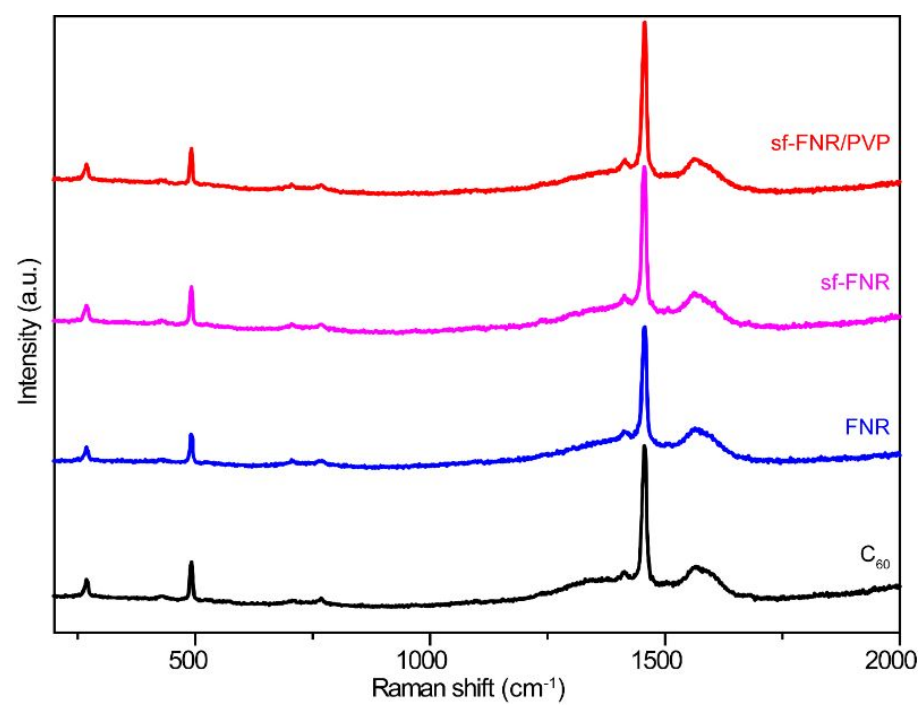

Figure S4. Raman spectra of sf-FNR/PVP (red), sf-FNR (purple), FNR (blue) and $\mathrm{C}_{60}$ (black). 


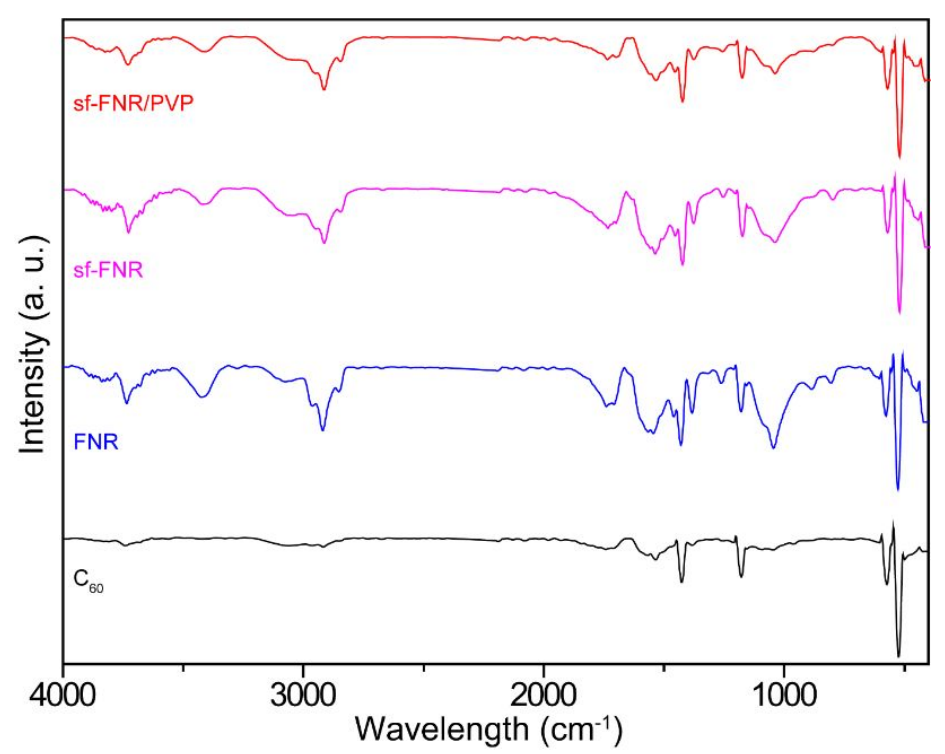

Figure S5. FTIR spectra of sf-FNR/PVP (red), sf-FNR (purple), FNR (blue) and $\mathrm{C}_{60}$ (black).

\section{Synthesis of sf-FNR/PVP@CoNi-LDH}

The sf-FNR/PVP@CoNi-LDH was prepared by co-precipitation method. ${ }^{5}$ To a solution containing $0.5 \mathrm{mmol}$ of $\mathrm{Ni}\left(\mathrm{NO}_{3}\right)_{2} \cdot 6 \mathrm{H}_{2} \mathrm{O}$ and $1 \mathrm{mmol}$ of $\mathrm{Co}\left(\mathrm{NO}_{3}\right)_{2} \cdot 6 \mathrm{H}_{2} \mathrm{O}$ added $40 \mathrm{mg}$ of sfFNR/PVP dispersed in $30 \mathrm{~mL}$ of EG and $10 \mathrm{~mL}$ of DI water, and then $7.5 \mathrm{mmol}$ of urea was introduced slowly. After vigorously stirred for $10 \mathrm{~min}$, the mixture was reflux for $3 \mathrm{~h}$. The precipitate was separated by filtration and dried at $60{ }^{\circ} \mathrm{C}$ for $24 \mathrm{~h}$ after washing with $\mathrm{EtOH}$ and DI water each three times. To optimize the electrocatalytic performance, different mass ratio of CoNi-LDH in sf-FNR/PVP@CoNi-LDH were also prepared by changing the mass of sfFNR/PVP from 20, 30, 40 to $50 \mathrm{mg}$, while keep other condition unchanged. The XRD pattern shown in Figure S6 confirmed the composition of the product, which contains the peaks at 10.8, $17.9,21.5,28.2,31.4$ and $33.6^{\circ}$ belonging to $\mathrm{C}_{60}$ (JCPDS \#44-0558) and 11.6, 25.2, 37.6 and $38.9^{\circ}$ ascribed to CoNi-LDH (JCPDS \#33-0429). The morphology of the CoNi-LDH anchored on the surface of sf-FNR/PVP exhibited ultrathin nanosheet as mentioned in the main text. 


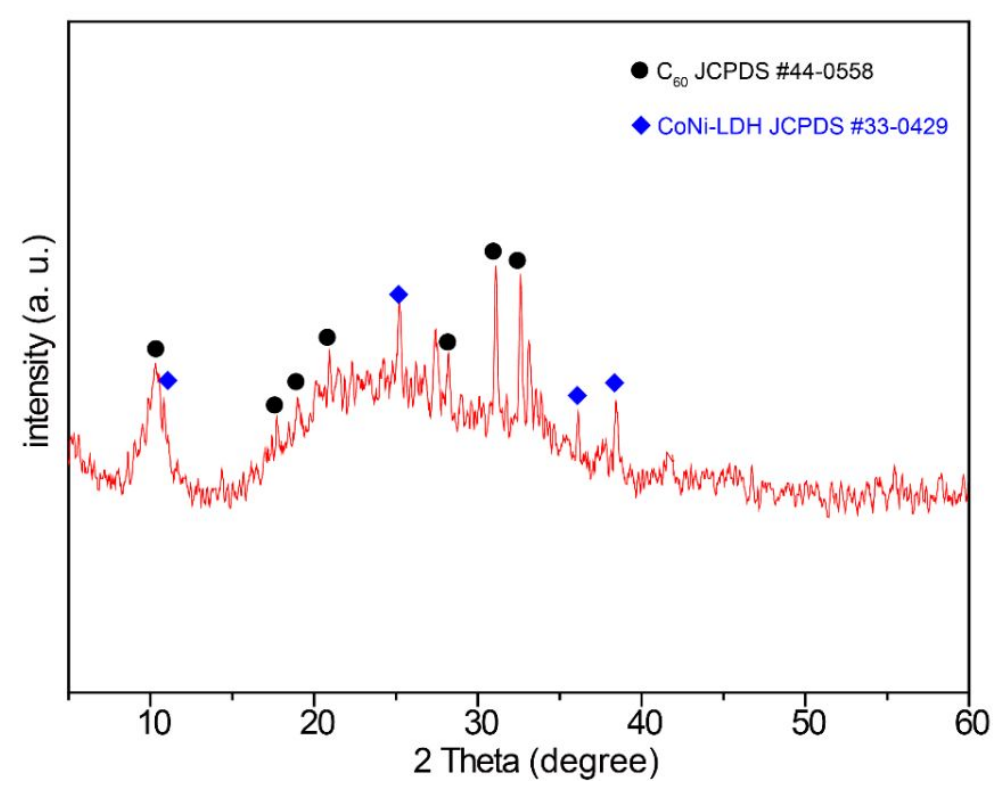

Figure S6. XRD pattern of sf-FNR/PVP@CoNi-LDH.

\section{Synthesis of p-NFNR@Ni-Co-P}

The p-NFNR@Ni-Co-P was synthesized by phosphorization of sf-FNR/PVP@CoNi-LDH.6 Briefly, $100 \mathrm{mg}$ of the obtained sf-FNR/PVP@CoNi-LDH and $1 \mathrm{~g}$ of $\mathrm{NaH}_{2} \mathrm{PO}_{2}$ were separately placed in a crucible with the latter in the upstream. The crucible was then put into a tube furnace under the protection of Ar atmosphere. When the temperature was increased to $350{ }^{\circ} \mathrm{C}$ with a rate of $2{ }^{\circ} \mathrm{C} / \mathrm{min}$, the furnace was continuously heated for $2 \mathrm{~h}$ before cooling to the room temperature. For comparison, Ni-Co-P was prepared under the similar condition except using CoNi-LDH as the precursor, which exhibited large blocks (Figure S8) compared to the nanoparticles dispersed on the as-obtained p-NFNR in p-NFNR@NiCoP (Figure S7).
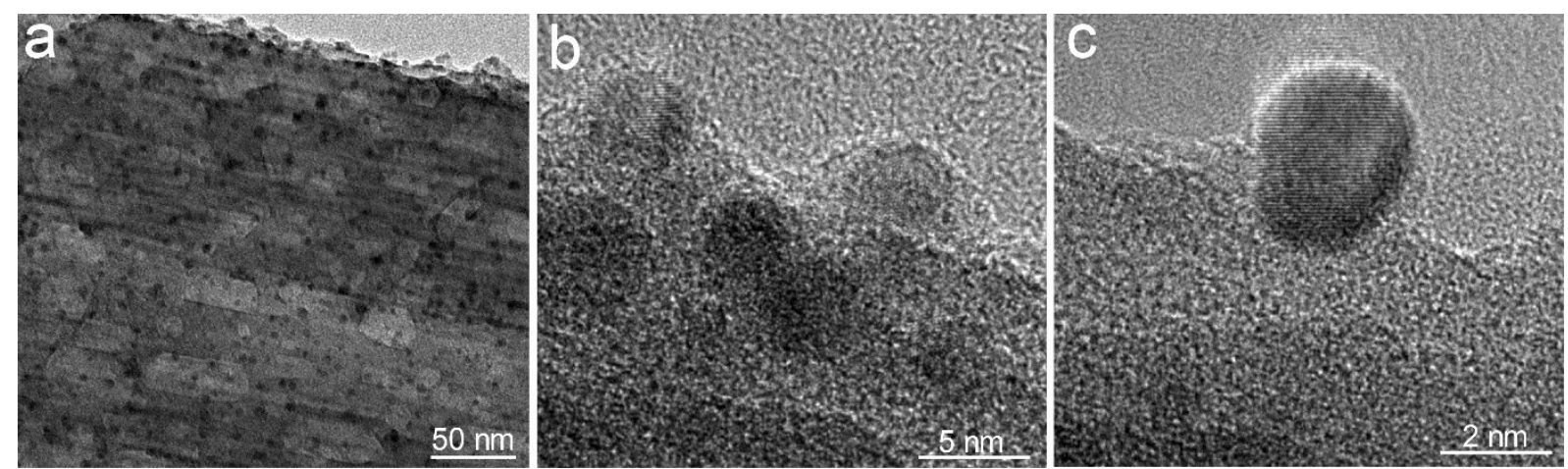

Figure S7. (a-c) TEM images of p-NFNR@Ni-Co-P showing the nanoparticles decorated on the porous surface of $\mathrm{p}-\mathrm{NFNR}$. 


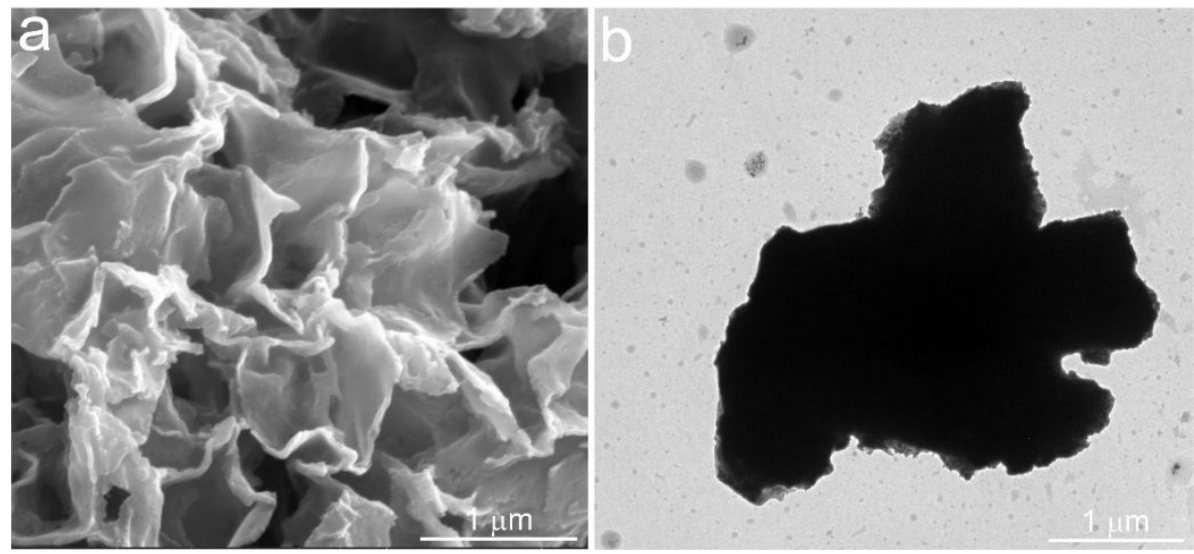

Figure S8. (a) SEM and (b) TEM image of Ni-Co-P.

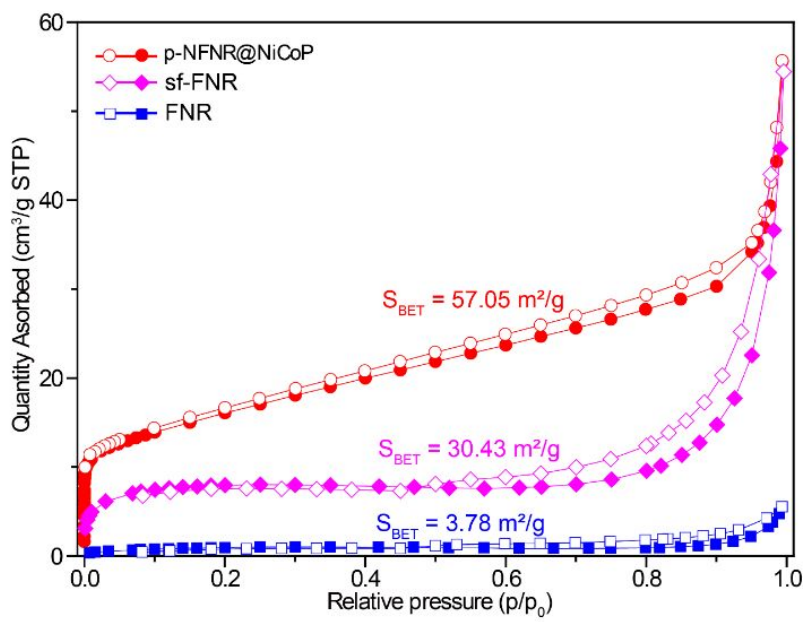

Figure S9. Nitrogen adsorption (solid circle) and desorption (empty circle) of p-NFNR@NiCo-P (red), sf-FNR (purple) and FNR (blue).

Figure S10 showed the XPS of p-NFNR@Ni-Co-P and Ni-Co-P. From Figure S10c, the peak at $853.93 \mathrm{eV}$ and $870.95 \mathrm{eV}$ were pointed to the $\mathrm{Ni}-\mathrm{P}$ bond, and the peaks located at 857.09 and $875.12 \mathrm{eV}$ could be ascribed to nickel oxide species. Two satellite peaks were presented at 862.60 and $881.34 \mathrm{eV} .{ }^{7}$ For the Co $2 \mathrm{p}$ spectrum displayed in Figure S10d, the peaks located at 778.90 and $793.60 \mathrm{eV}$ matched well with the Co-P bond in CoP, and peaks at 782.02 and 798.14 eV could be ascribed to the surface oxidized CoP. The other two peaks with binding energy (BE) at 785.94 and $803.26 \mathrm{eV}$ could be the satellite signals. ${ }^{8}$ 

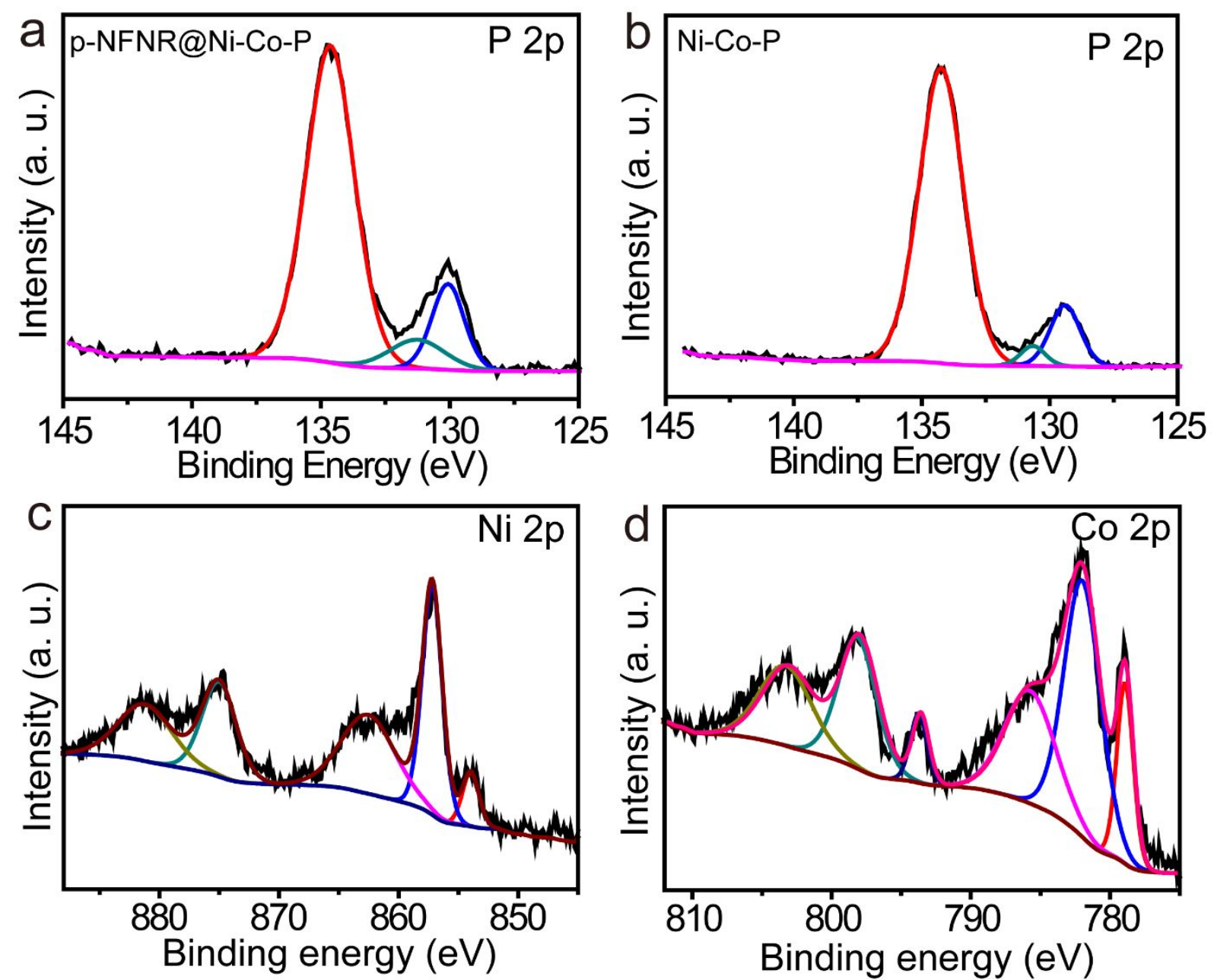

Figure S10. XPS profiles of P 2p for p-NFNR@Ni-Co-P (a), P 2p (b), Ni 2p (c) and Co 2p

(d) for Ni-Co-P.

\section{Electrochemical measurements}

All the half-cell electrochemical measurements were performed using a standard threeelectrode setup equipped on a CHI660E workstation. The glass carbon electrode (GCE) was used as working electrode, saturated calomel electrode (SCE) and graphite rod as reference and counter electrode, respectively. The diameter of the GCE was $3 \mathrm{~mm}$. The working electrode was prepared by the following procedure: the catalyst powder was first dispersed in isopropanol solution with Nafion (5 wt.\%), and then drop-cast onto the surface of GCE with a loading amount of ca. $0.26 \mathrm{mg} \mathrm{cm}^{-2}$. All the potentials were calibrated to reversible hydrogen potential (RHE) using the equation of $\mathrm{E}_{\mathrm{RHE}}=\mathrm{E}_{\mathrm{SCE}}+0.24+0.059 \mathrm{pH} .{ }^{9}$ For the overall water splitting, a two-electrode electrolyzer cell was fabricated. Three individual cells with configuration of p- 
NFNR@Ni-Co-P\|p-NFNR@Ni-Co-P, Ni-Co-P\|Ni-Co-P and $\mathrm{IrO}_{2} \| 20$ wt.\% Pt/C were used. The HER, OER and overall water splitting were conducted in $1 \mathrm{M} \mathrm{KOH}$. Before test, the electrolyzer cell was saturated with nitrogen gas for $30 \mathrm{~min}$ to remove the air.

The LSV curves were measured with a sweeping rate of $5 \mathrm{mV} \mathrm{s}^{-1}$. To evaluate the reaction kinetics, the polarization curve was then replotted as voltage vs. log current density to obtain the Tafel plot. By fitting the linear portion of the Tafel plot to the Tafel equation of $\eta=a+b$ $\log \mathrm{j}(\eta$ refers to the overpotential, $b$ is the Tafel slope and a denotes the intercept), the Tafel slope (b) can be obtained. ${ }^{10}$

The electrochemical impedance spectroscopy (EIS) were performed under open circuit potentials for all materials and the frequency range from $0.1 \mathrm{~Hz}$ to $100 \mathrm{kHz}$ with an amplitude of $5 \mathrm{mV}$ were used to carry out the experiment. The impedance data were represented by the Nyquist curve. ${ }^{11}$

For the double-layer capacitor $\left(\mathrm{C}_{\mathrm{dl}}\right)$ data, $\mathrm{CV}$ curves were recorded in the non-Faradic region with scanning rate of $20,40,60,80,100$ and $120 \mathrm{mV} \mathrm{s}^{-1}$, and the $\mathrm{C}_{\mathrm{dl}}$ can be obtained by plotting the current difference $(\Delta \mathrm{j})$ against the scanning rate. The electrochemical active surface area (ECSA) was estimated by the following equation, ${ }^{12,13}$

$\mathrm{ECSA}=\mathrm{C}_{\mathrm{dl}} / \mathrm{C}_{\mathrm{s}} \times \mathrm{S}$

where $\mathrm{C}_{\mathrm{s}}$ represents the specific capacitance on the electrode surface and $\mathrm{S}$ is the actual area of the working electrode. Generally, $\mathrm{Cs}$ is in the range of $20-60 \mu \mathrm{F} \mathrm{cm}{ }^{-2}$, herein the averaged $\mathrm{C}_{\mathrm{s}}$ value of $40 \mu \mathrm{F} \mathrm{cm}^{-2}$ was used according the literature.

To assess the stability of the catalysts, LSV curves before and after continuous CV scanning for 2000 cycles with a scan rate of $100 \mathrm{mV} \mathrm{s}^{-1}$ were collected. The long-term chronoamperometry test was applied at a voltage to drive current density of $10 \mathrm{~mA} \mathrm{~cm}{ }^{-2}$.

The Faradic efficiency of gas evolution was carried out using the water drainage method. The hydrogen gas amount was calculated using the Faradic law (Equation (2)) and ideal gas equation (Equation (3)) assuming two electrons was transferred to produce one $\mathrm{H}_{2}$ molecule: ${ }^{14}$ 


$$
\begin{aligned}
& \mathrm{n}(\text { theo. })=\mathrm{Q} / 2 \mathrm{~F} \\
& \mathrm{n}(\text { exp. })=\mathrm{PV} / \mathrm{RT}
\end{aligned}
$$

where the total amount of charge $\mathrm{Q}(\mathrm{C})$ can be obtained by $\mathrm{Q}=\mathrm{I} \times \mathrm{t}$. Then the Faradic efficiency $\left(\Phi_{\text {eff. }}\right)$ can be expressed as:

$$
\Phi_{\text {eff. }}=\mathrm{n}(\text { exp. }) / \mathrm{n}(\text { theo. })=2 \mathrm{FPV} / \mathrm{RTIt}
$$

where $\mathrm{F}$ is the Faradic constant $\left(96485 \mathrm{C} \mathrm{mol}^{-1}\right), \mathrm{P}$ is the standard atmospheric pressure (101325 Pa), $\mathrm{V}$ is the gas volume $\left(\mathrm{m}^{3}\right), \mathrm{R}$ is the ideal gas constant $\left(8.314 \mathrm{~J} \mathrm{~mol}^{-1} \mathrm{~K}^{-1}\right), \mathrm{T}$ is the temperature $(\mathrm{K}), \mathrm{I}$ is the current passed the electrode, and $\mathrm{t}$ is the electrolysis time.

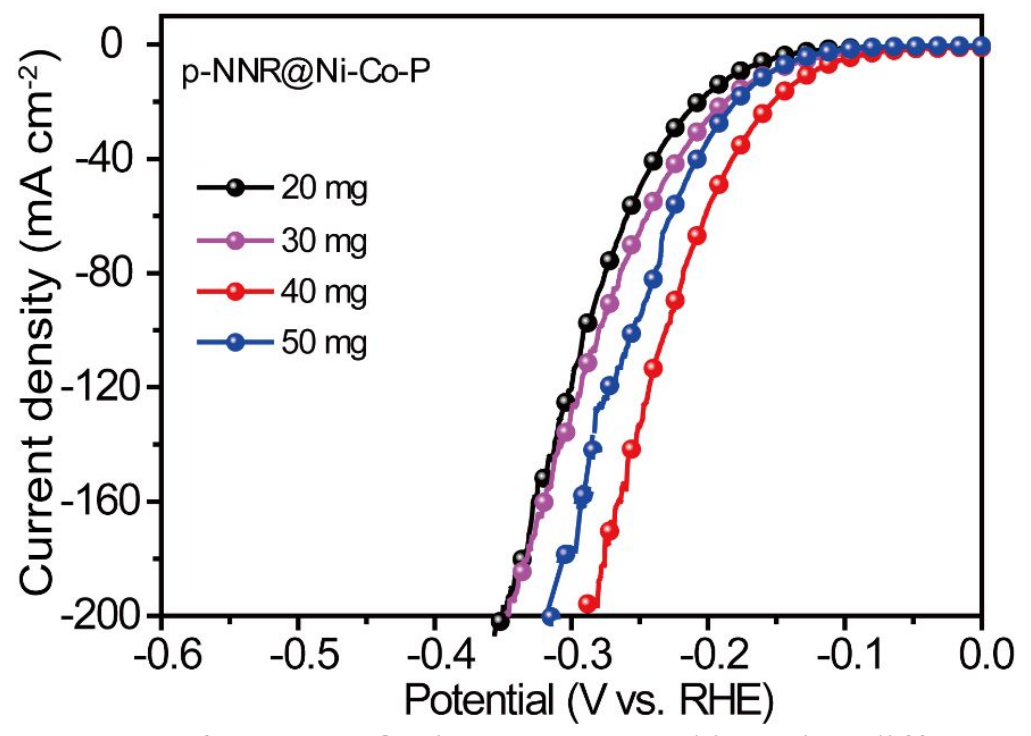

Figure S11. LSV curves of p-NFNR@Ni-Co-P prepared by using different mass loading of sf-FNR/PVP under a scan rate of $5 \mathrm{mV} \mathrm{s}^{-1}$ in $1 \mathrm{M} \mathrm{KOH}$.

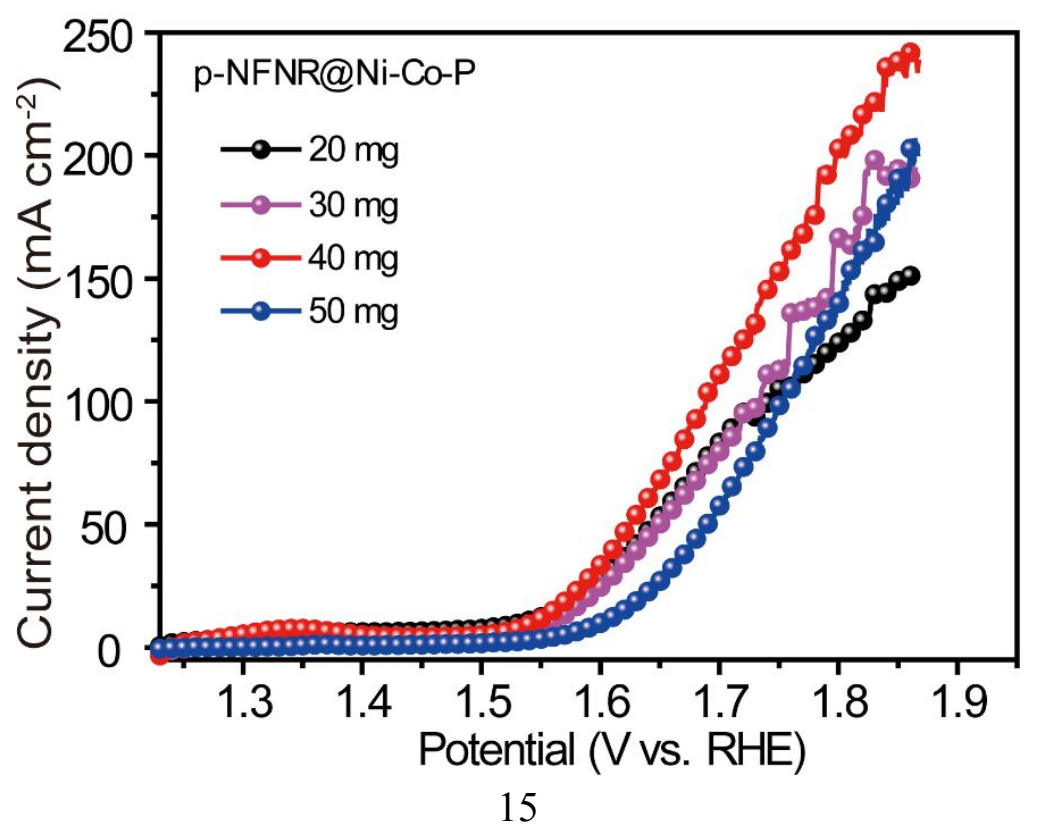


Figure S12. LSV curves of p-NFNR@Ni-Co-P prepared by using different mass loading of sf-FNR/PVP under a scan rate of $5 \mathrm{mV} \mathrm{s}^{-1}$ in $1 \mathrm{M} \mathrm{KOH}$.
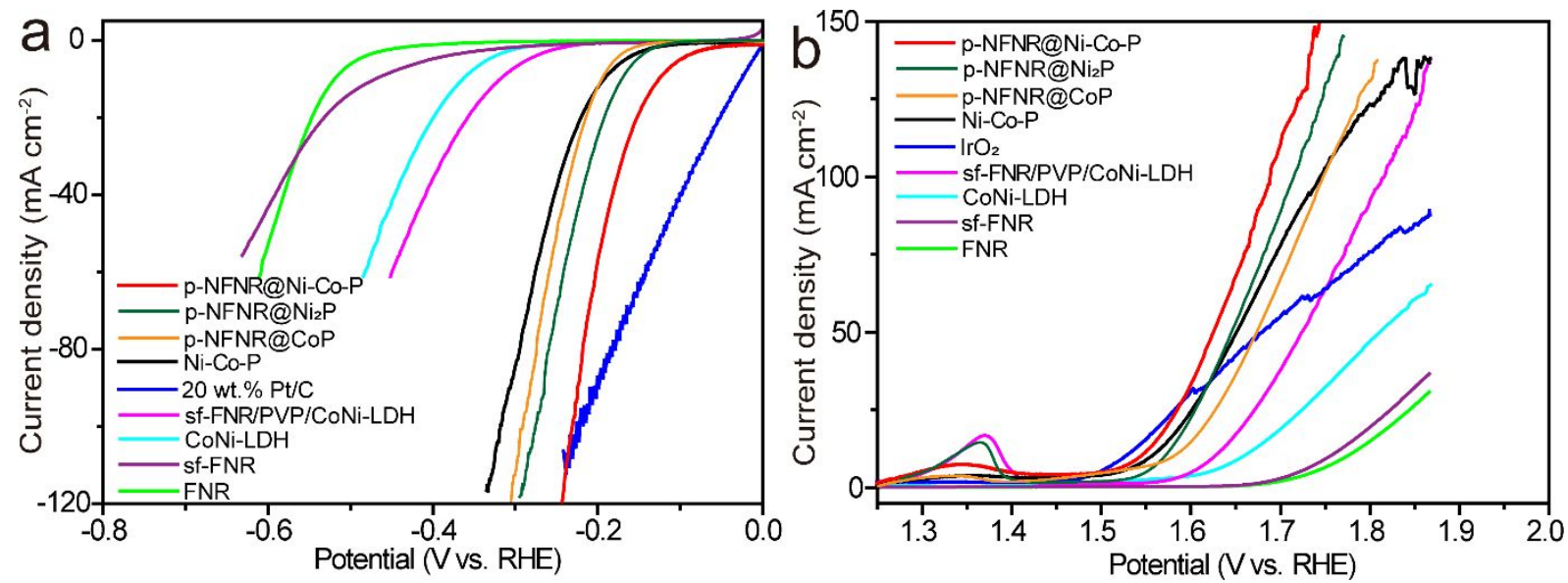

Figure S13. Polarization plots of HER (a) and OER (b) for p-NFNR@Ni-Co-P (red), pNFNR@Ni $\mathrm{Ni}_{2} \mathrm{P}$ (dark green), p-NFNR@CoP (orange), Ni-Co-P (black), 20 wt.\% Pt/C and $\mathrm{IrO}_{2}$ (blue), sf-FNR/PVP/CoNi-LDH (pink), CoNi-LDH (cyan), sf-FNR (purple) and FNR (light green), respectively. 

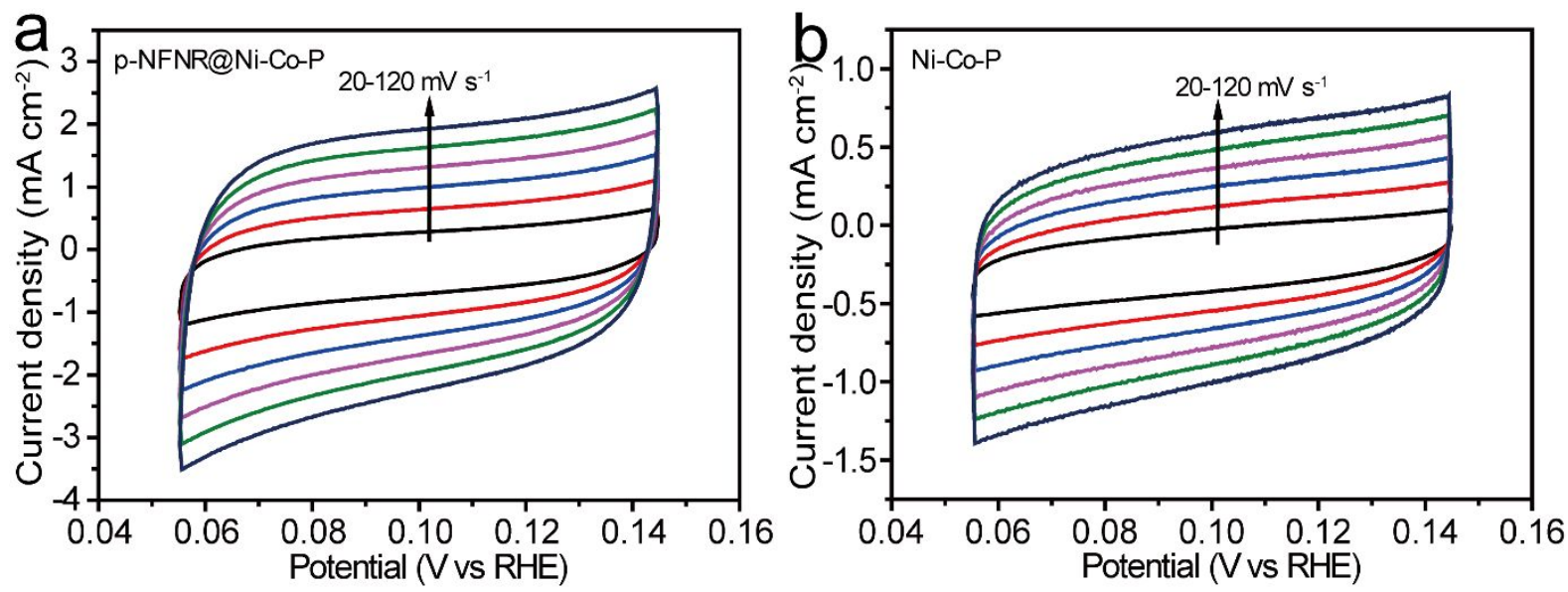

Figure S14. CV curves of (a) p-NFNR@Ni-Co-P and (b) Ni-Co-P with different scanning rate from 20 to $120 \mathrm{mV} \mathrm{s}^{-1}$ in the range of $0.05-0.15 \mathrm{~V}$ in $1 \mathrm{M} \mathrm{KOH}$ for HER.
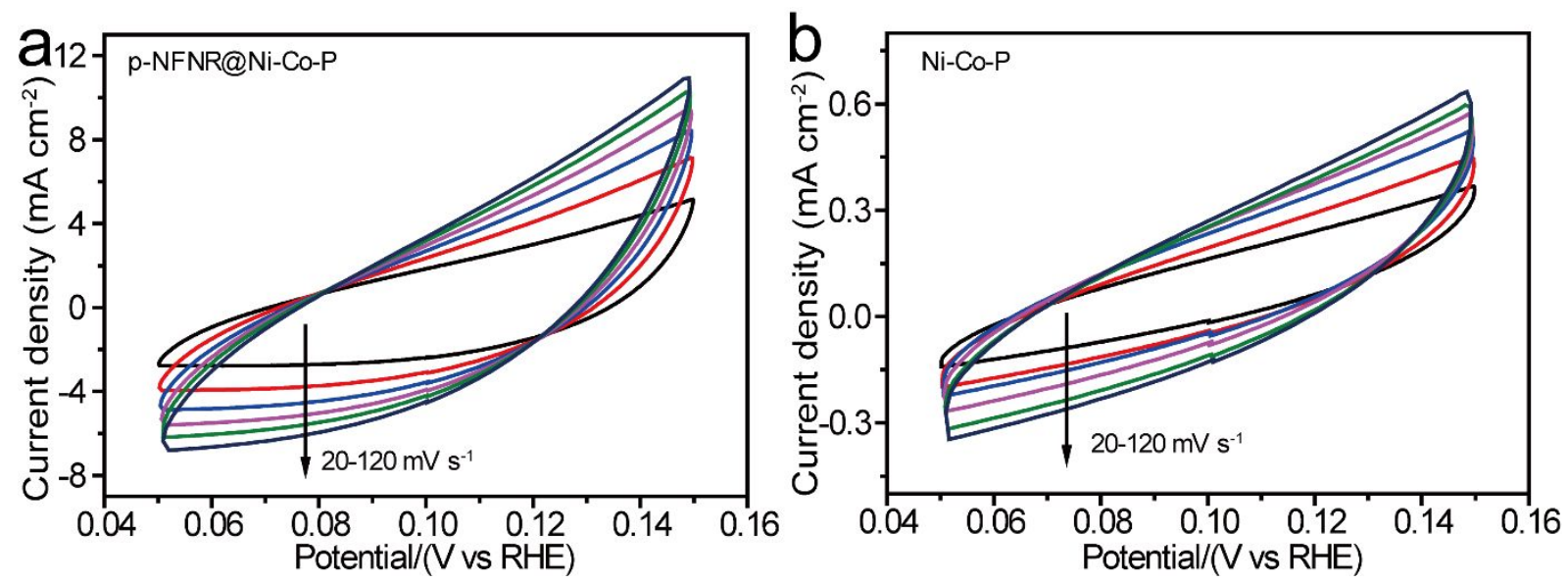

Figure S15. CV curves of (a) p-NFNR@Ni-Co-P and (b) Ni-Co-P with different scanning rate from 20 to $120 \mathrm{mV} \mathrm{s}^{-1}$ in the range of $0.05-0.15 \mathrm{~V}$ in $1 \mathrm{M} \mathrm{KOH}$ for OER. 

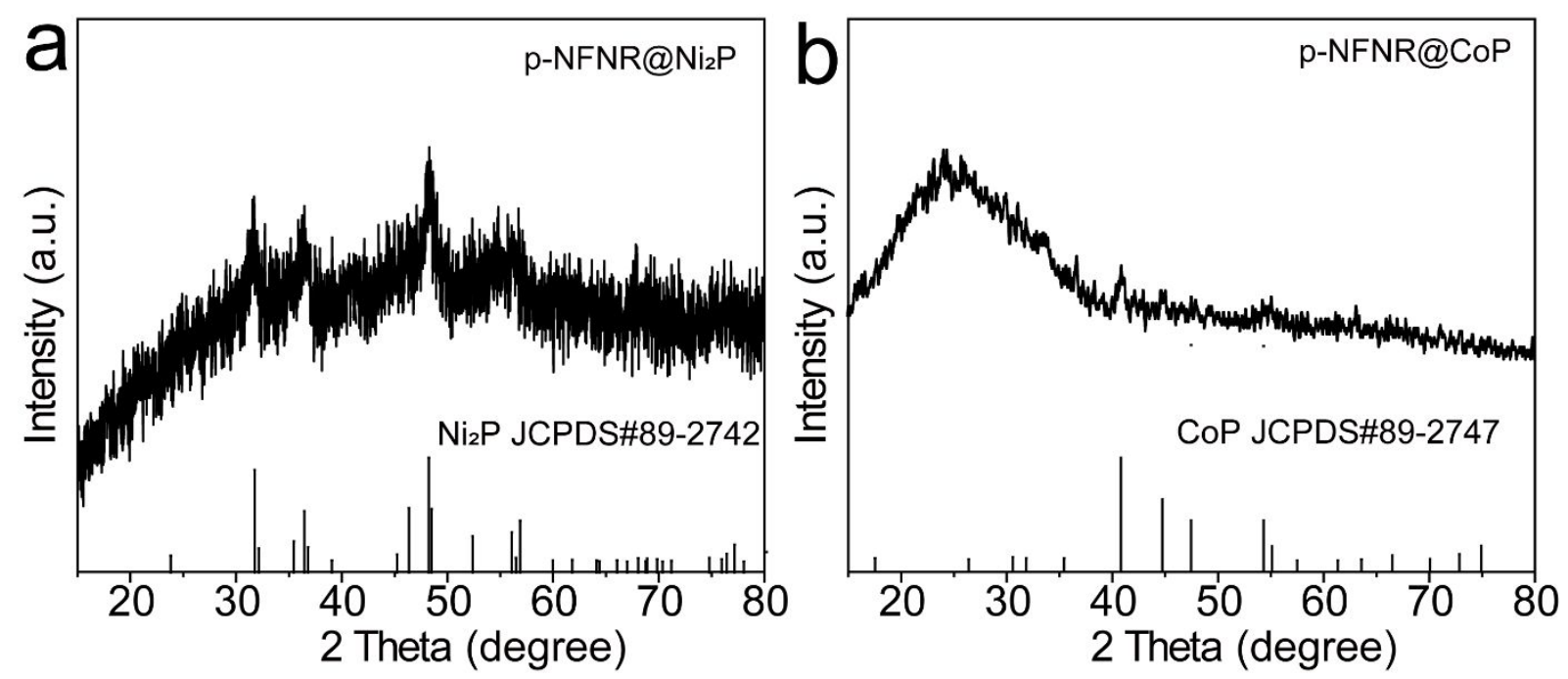

Figure S16. XRD patterns of (a) p-NFNR@Ni $2 \mathrm{P}$ and (b) p-NFNR@CoP.
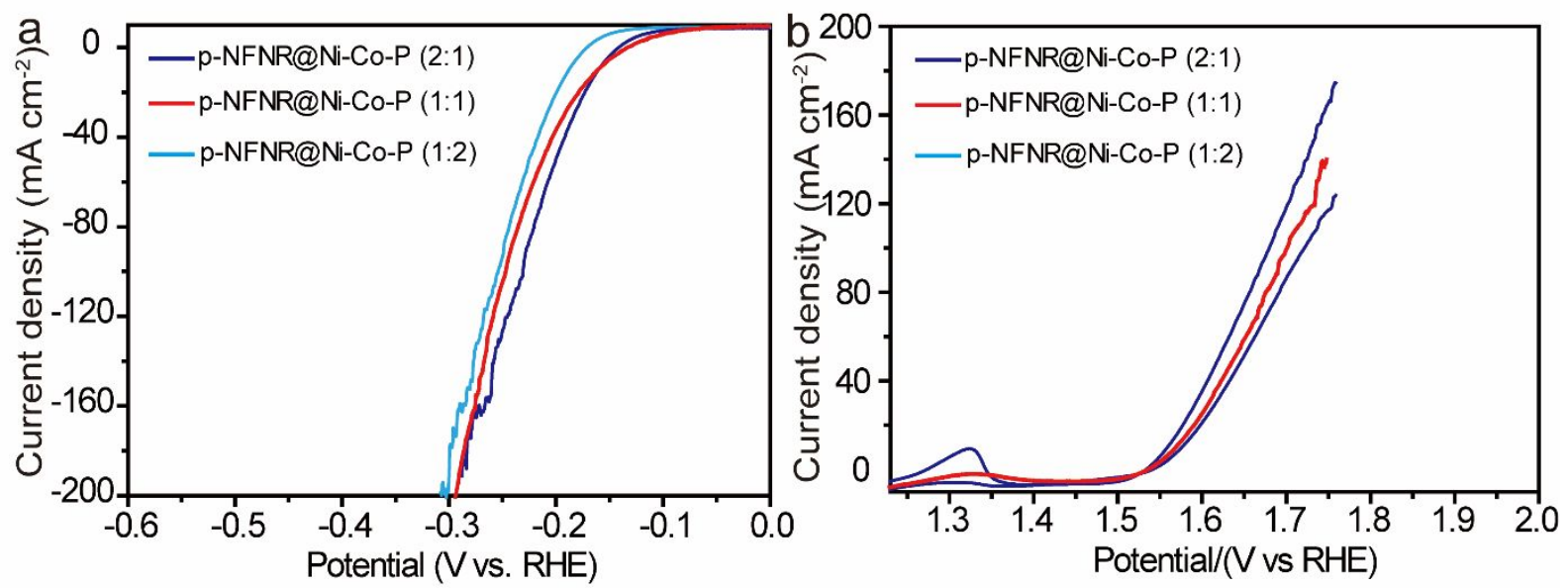

Figure S17. Polarization plots of HER (a) and OER (b) for p-NFNR@Ni-Co-P (1:1) (red), p-

NFNR@Ni-Co-P (2:1) (dark blue),p-NFNR@Ni-Co-P (1:2) (light blue)with the samples with different $\mathrm{Ni} / \mathrm{Co}$ ratio. 

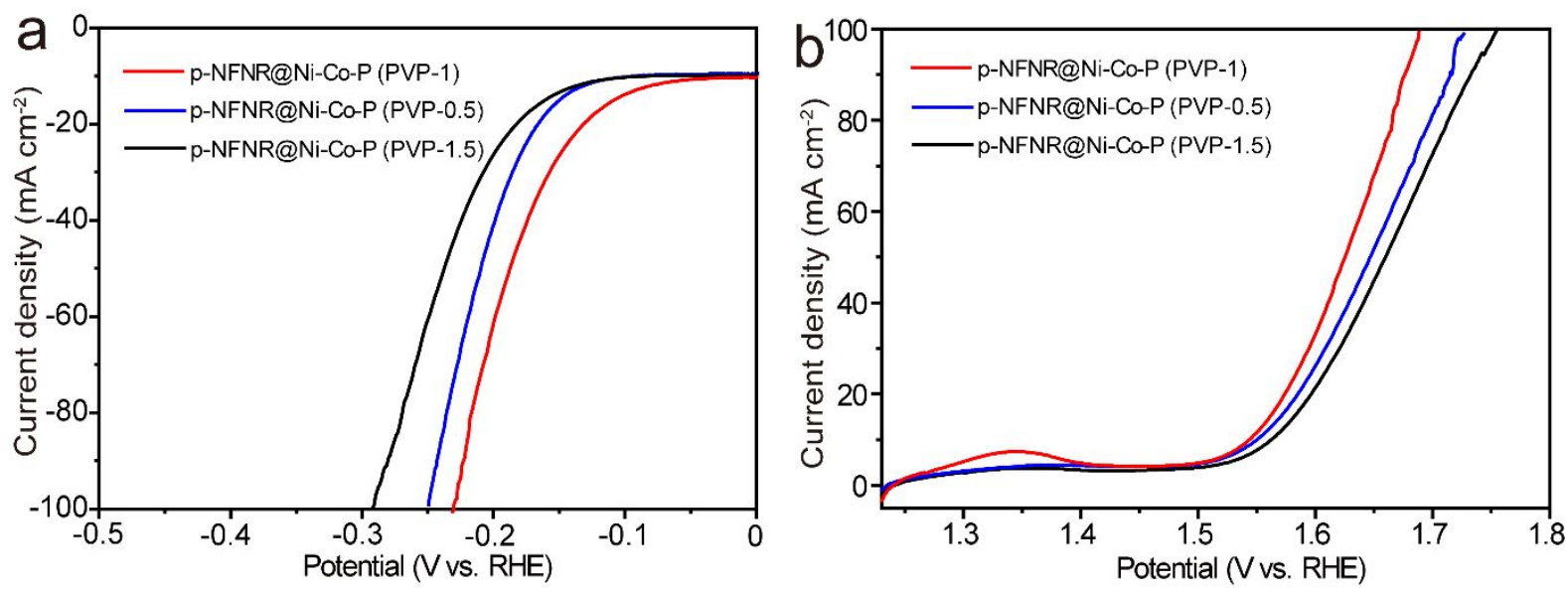

Figure S18. Polarization plots of HER (a) and OER (b) for p-NFNR@Ni-Co-P (PVP-1) (red), p-NFNR@Ni-Co-P (PVP-0.5) (blue), p-NFNR@Ni-Co-P (PVP-1.5) (black)with the samples with different addition amount of PVP.

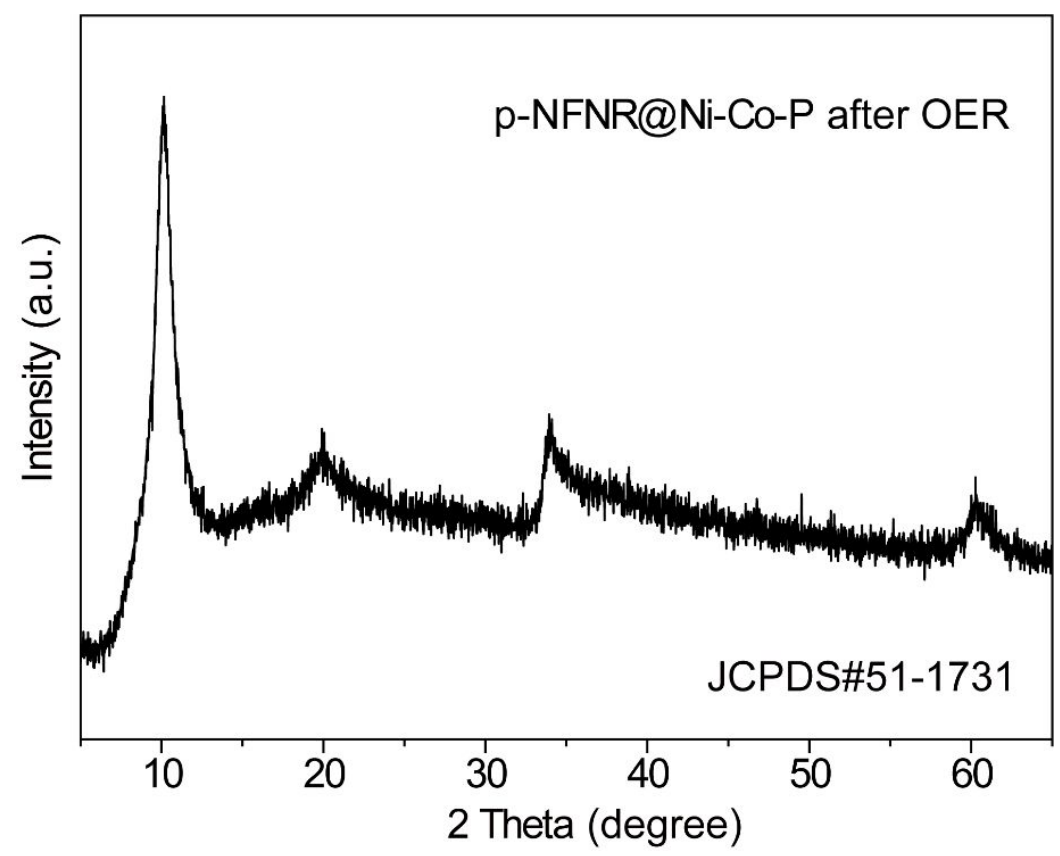

Figure S19. XRD patterns of p-NFNR@Ni-Co-P after OER test. 

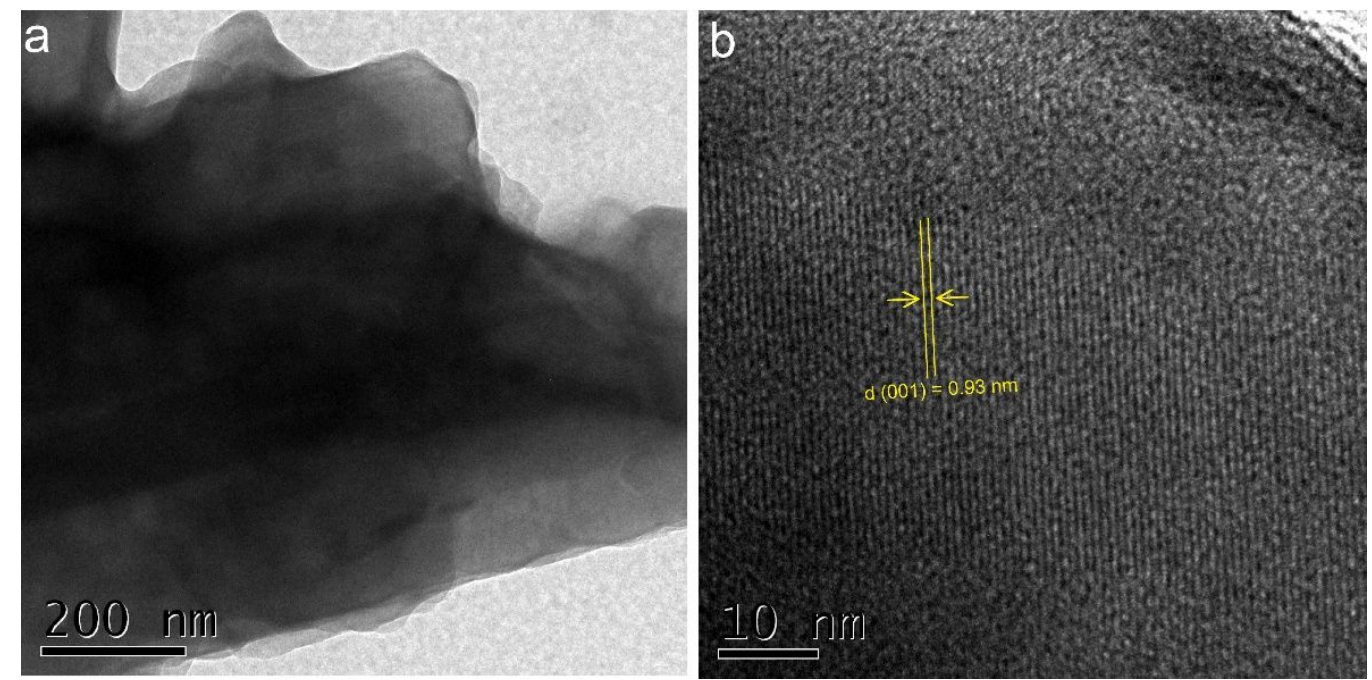

Figure S20. (a) Typical TEM image and (b) HRTEM image of p-NFNR@Ni-Co-P after longterm $I$-t test for OER measurement.
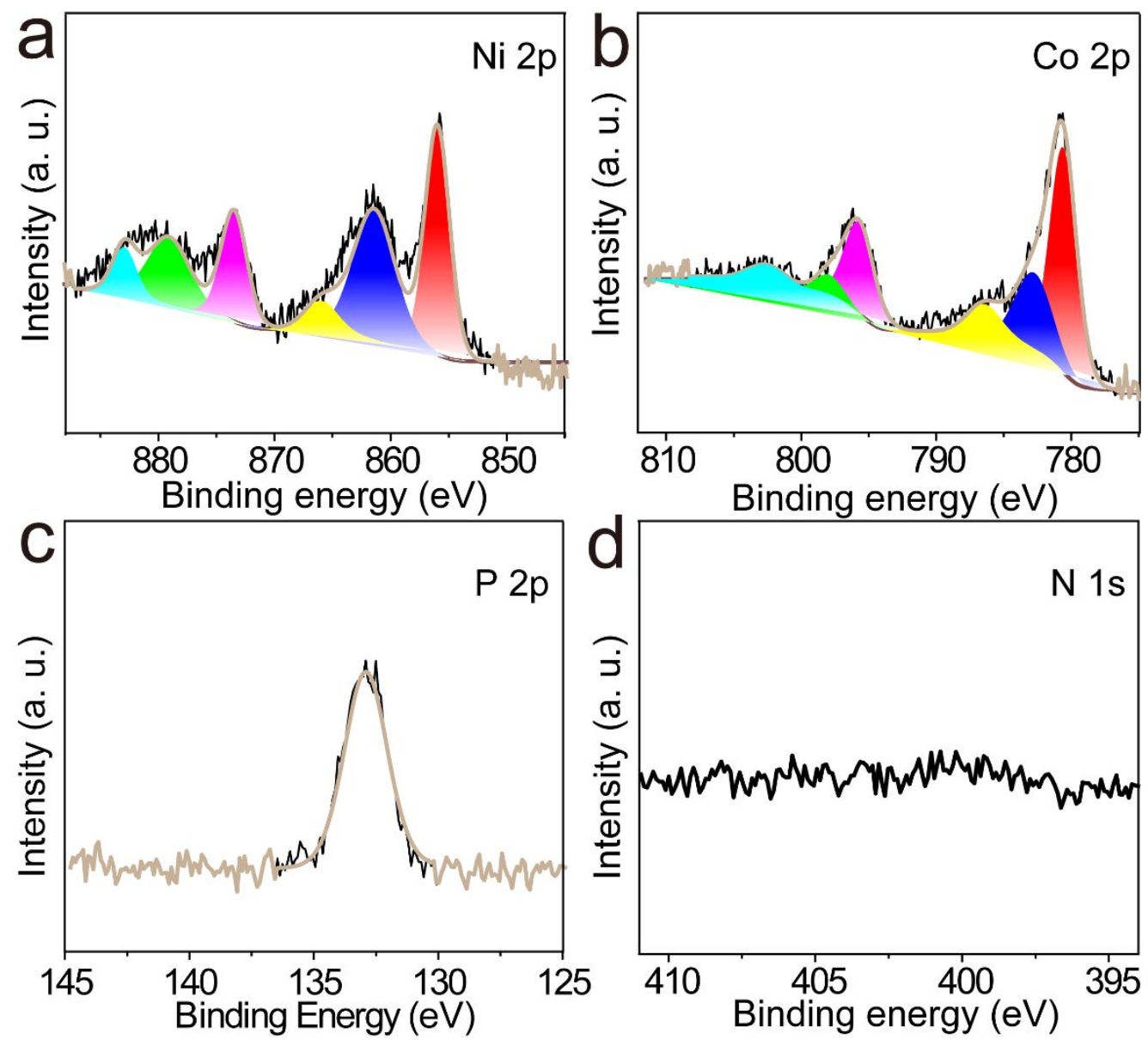

Figure S21. XPS profiles of p-NFNR@Ni-Co-P after OER test. (a) Ni 2p, (b) Co 2p, (c) P 2p and (d) N $1 \mathrm{~s}$. 


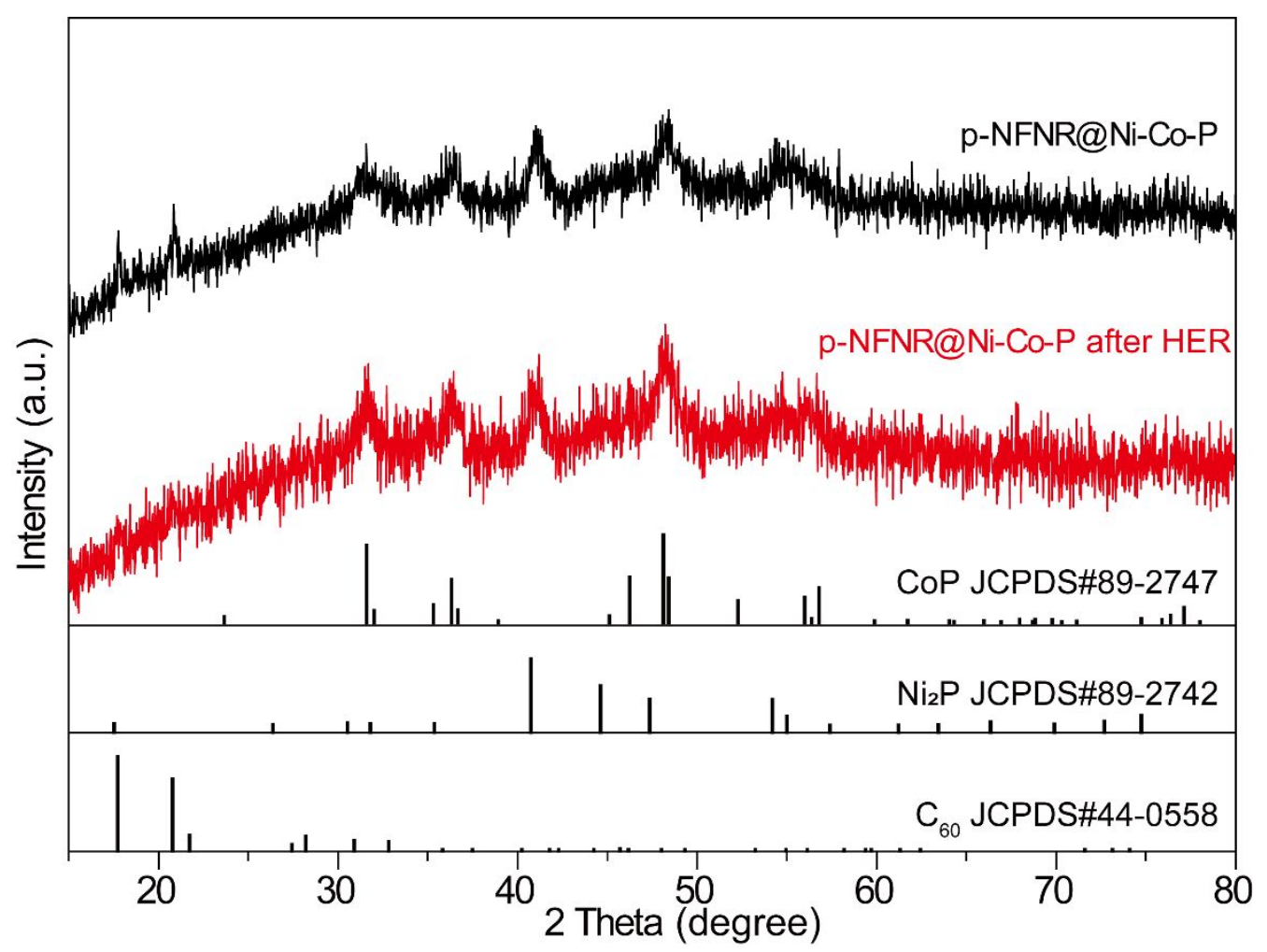

Figure S22. XRD patterns of p-NFNR@Ni-Co-P before (black) and after (red) HER test.
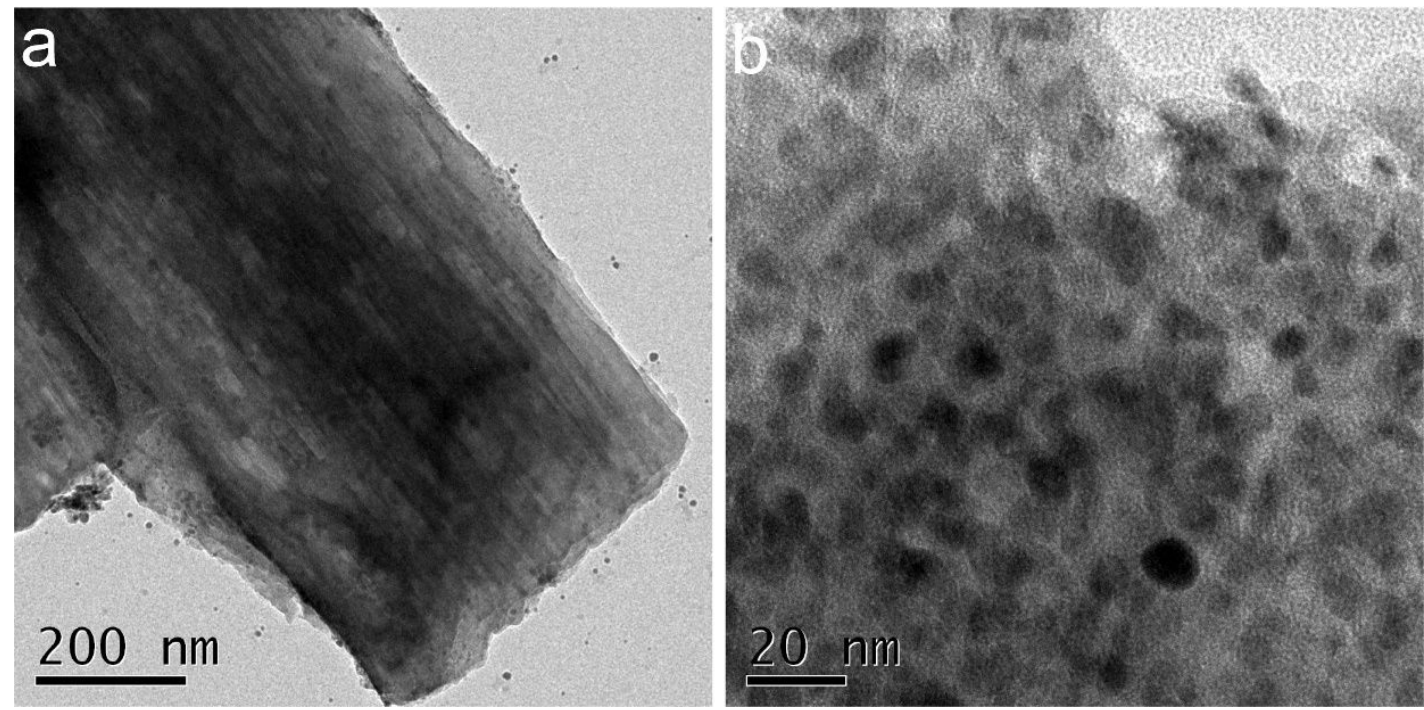

Figure S23. (a) Typical TEM image and (b) HRTEM image of p-NFNR@Ni-Co-P after longterm $I$-t test for HER measurement. 


\section{Theoretical Section:}

$\mathrm{NiCoP}(111) / \mathrm{F}$
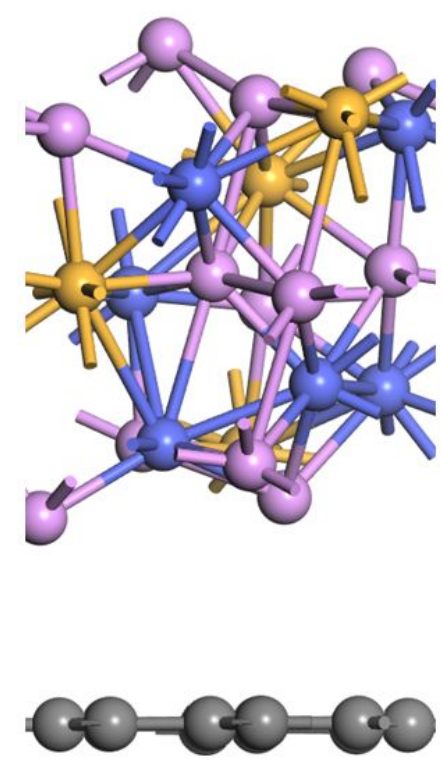

$\operatorname{NiCoP}(111)$

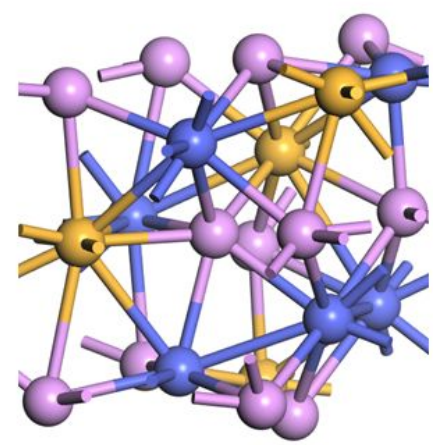

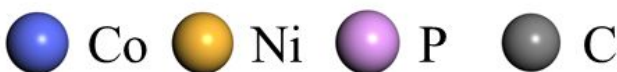

Figure S24. The structures of $\mathrm{NiCoP} / \mathrm{F}$ and $\mathrm{NiCoP}$.

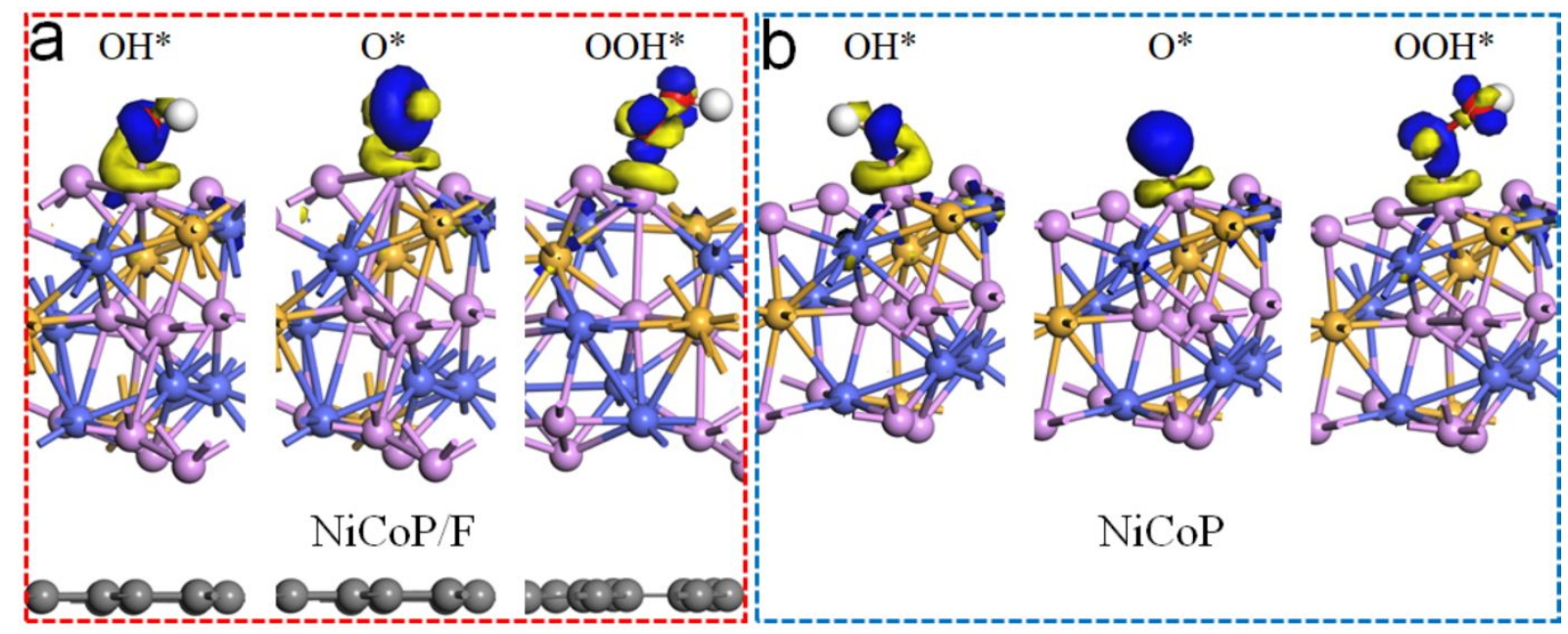

Figure S25. Charge differential density of the most stable adsorption configurations of $\mathrm{OH}^{*}$, $\mathrm{O}^{*}$, and $\mathrm{OOH}^{*}$ on $\mathrm{NiCoP} / \mathrm{F}$ (a) and $\mathrm{NiCoP}$ (b). The iso-surface value of charge differential density is $0.05 \mathrm{e} / \AA^{3}$, blue and yellow represent charge depletion and accumulation. "*" means the chemical adsorption. 
Table S1. The ICP and XPS results of atomic ratio (\%) of Ni, Co, P and N for the optimal sample of p-NFNR@Ni-Co-P.

\begin{tabular}{|c|c|c|c|c|}
\hline & Ni & Co & P & N \\
\hline ICP & 12.2 & 13.6 & 11.5 & - \\
\hline XPS & 8.9 & 9.6 & 8.2 & 3.04 \\
\hline
\end{tabular}


Table S2. The HER properties of p-NFNR@Ni-Co-P compared with other non-precious metal-based OER catalysts in $1 \mathrm{M} \mathrm{KOH}$.

\begin{tabular}{|c|c|c|}
\hline Catalysts & $\eta_{10}(\mathrm{mV})$ & References \\
\hline p-NFNR@Ni-Co-P & 125 & This work \\
\hline $\mathrm{Ti}_{3} \mathrm{C}_{2} @ \mathrm{mNiCoP}$ & 127 & $\begin{array}{c}\text { ACS Appl. Mater. Interfaces, 2020, } \\
12,18570-18577\end{array}$ \\
\hline NCPP NCs & 140 & $\begin{array}{c}\text { Electrochim. Acta, 2020, 337, } \\
135799 .\end{array}$ \\
\hline $\mathrm{MoP} / \mathrm{NPG}$ & 126 & $\begin{array}{l}\text { Appl. Catal. B-Environ., 2020, 260, } \\
118196 .\end{array}$ \\
\hline $\mathrm{Co}_{2} \mathrm{P} / \mathrm{CoNPC}$ & 130 & Adv. Mater., 2020, 32, 2003649. \\
\hline $\mathrm{Ni}_{0.85} \mathrm{Se} / \mathrm{rGO}$ & 128 & $\begin{array}{l}\text { Int. J. Hydrogen Energ., 2020, 45, } \\
\text { 10486-10493. }\end{array}$ \\
\hline FeCo-LDH/PANI & 104 & $\begin{array}{l}\text { Int. J. Hydrogen Energ., 2020, 45, } \\
\text { 26989-26999. }\end{array}$ \\
\hline $\mathrm{Ni} @ \mathrm{~B}-\mathrm{C} 500{ }^{\circ} \mathrm{C}$ & 176 & $\begin{array}{l}\text { J. Electroanal. Chem. 2020, 869, } \\
114085\end{array}$ \\
\hline VNMS & 110 & $\begin{array}{c}\text { ACS Appl. Mater. Interfaces 2021, } \\
13,765-780 .\end{array}$ \\
\hline $\mathrm{NiCoN} / \mathrm{C}$ nanocages & 103 & Adv. Mater., 2018, 1805541 \\
\hline $\mathrm{Co}-\mathrm{N} / \mathrm{GF}-900$ & 165 & ACS Catal., 2018, 8, 4637-4644 \\
\hline $\mathrm{Co}-\mathrm{P} \mathrm{I}$ & 175 & $\begin{array}{c}\text { ACS Appl. Mater. Interfaces, 2018, } \\
\text { 10, 18, 15673-15680 }\end{array}$ \\
\hline $\mathrm{Cu}_{0.3} \mathrm{Co}_{2.7} \mathrm{P} / \mathrm{NC}$ & 220 & $\begin{array}{c}\text { Adv. Energy Mater., 2017, 7, } \\
1601555\end{array}$ \\
\hline SSUCo-900 & 247 & $\begin{array}{l}\text { ACS Appl. Mater. Interfaces, 2017, } 9 \text {, } \\
\text { 28566-28576 }\end{array}$ \\
\hline $\mathrm{C} / \mathrm{LDH} / \mathrm{S}$ & 142 & Adv. Mater., 2017, 29, 1606814 \\
\hline $\mathrm{NiCoP} / \mathrm{rGO}$ & 209 & Adv. Funct. Mater., 2016, 26, 6785 \\
\hline CP@Ni-P & $\begin{array}{c}117 \\
250\left(\eta_{100}\right)\end{array}$ & $\begin{array}{l}\text { Adv. Funct. Mater. 2016, 26, 4067- } \\
4077\end{array}$ \\
\hline $\mathrm{CoO}_{\mathrm{x}} @ \mathrm{CN}$ & 232 & $\begin{array}{l}\text { J. Am. Chem. Soc., } 2015,137,2688- \\
2694\end{array}$ \\
\hline Co@NG & 220 & Adv. Funct. Mater., 2016, 26, 4397 \\
\hline $\mathrm{CoP} / \mathrm{rGO}-400$ & 150 & Chem. Sci., 2016, 7, 1690-1695 \\
\hline $\mathrm{c}-\mathrm{CoSe}_{2} / \mathrm{CC}$ & 190 & Adv. Mater., 2016, 28, 7527 \\
\hline
\end{tabular}


Table S3. The OER properties of p-NFNR@Ni-Co-P compared with other non-precious metal-based HER catalysts in $1 \mathrm{M} \mathrm{KOH}$.

\begin{tabular}{|c|c|c|c|}
\hline Catalysts & $\eta_{10}(\mathrm{mV})$ & Substrate & References \\
\hline p-NFNR@Ni-Co-P & 272 & Glassy carbon (GC) & This work \\
\hline Fe-NiCoP/PBA HNCs & 290 & GC & $\begin{array}{l}\text { Electrochim. Acta, 2021, } \\
\text { 367, } 137492 .\end{array}$ \\
\hline $\mathrm{NiCoP} / \mathrm{NF}$ & 253 & Nickel foam (NF) & $\begin{array}{l}\text { J. Power Source, 2021, 484, } \\
229269 .\end{array}$ \\
\hline $\mathrm{NiCo}_{2} \mathrm{~S}_{4} @ \mathrm{NiFe} \mathrm{LDH}$ & $287 *$ & $\begin{array}{l}\text { Rotating disk } \\
\text { electrode (RDE) }\end{array}$ & $\begin{array}{c}\text { Appl. Catal. B-Environ., } \\
\text { 2021, 286, } 119869 .\end{array}$ \\
\hline NiVFe LDH & 269 & $\mathrm{GC}$ & $\begin{array}{l}\text { Inorg. Chem. Front., 2019, 6, } \\
\text { 1890-1896. }\end{array}$ \\
\hline NCPP NCs & 291 & $\mathrm{GC}$ & $\begin{array}{c}\text { Electrochim. Acta, } 2020 \\
\text { 337, } 135799 .\end{array}$ \\
\hline NiFeV LDH & 287 & GC & $\begin{array}{l}\text { Adv. Funct. Mater., 2021, } \\
\text { 31, } 2009743 .\end{array}$ \\
\hline $\mathrm{Fe}-\mathrm{Co}_{3} \mathrm{O}_{4} \mathrm{HHNPs}$ & 262 & $\mathrm{RDE}$ & $\begin{array}{l}\text { Adv. Mater., 2020, 32, } \\
2002235 .\end{array}$ \\
\hline $\mathrm{Fe}-\mathrm{Co}$ PBA nanoboxes & 269 & $\begin{array}{c}\text { Carbon fiber paper } \\
\text { (CFP) }\end{array}$ & $\begin{array}{c}\text { Energy Environ. Sci., } 2019, \\
12,3348-3355 .\end{array}$ \\
\hline $\mathrm{Co}_{2}(\mathrm{OH})_{3} \mathrm{Cl}$ & 270 & $\mathrm{GC}$ & $\begin{array}{l}\text { Adv. Mater., 2019, 31, } \\
1805127 .\end{array}$ \\
\hline NiFe LDH-US & 330 & GC & $\begin{array}{l}\text { Angew. Chem. Int. Ed., } \\
\text { 2017, 56, 3897-3900. }\end{array}$ \\
\hline CoP/NCNHP & 310 & GC & $\begin{array}{c}\text { J. Am. Chem. Soc., } 2018 \\
140,7,2610-2618 .\end{array}$ \\
\hline CoP nanosheets & 265 & CFP & $\begin{array}{l}\text { ChemElectroChem, 2019, 6, } \\
5469 .\end{array}$ \\
\hline CoP@NPC & 300 & GC & $\begin{array}{l}\text { Int. J. Hydrogen Energ., } \\
\text { 2019, 44, 24342-24352. }\end{array}$ \\
\hline $\begin{array}{c}\mathrm{Fe}_{0.33} \mathrm{Co}_{0.67} \mathrm{OOH} \\
\text { PNSAs/CFC }\end{array}$ & 266 & CFP & $\begin{array}{c}\text { Angew. Chem. Int. Ed. 2018, } \\
\text { 57, 2672-2676. }\end{array}$ \\
\hline $\mathrm{NiCoP} / \mathrm{C}$ & 330 & $\mathrm{GC}$ & $\begin{array}{c}\text { Angew. Chem., 2017, 129, } \\
\text { 3955-3958. }\end{array}$ \\
\hline $\mathrm{Ni}(\mathrm{OH})_{2}-\mathrm{Au}$ & 270 & $\mathrm{GC}$ & $\begin{array}{c}\text { J. Am. Chem. Soc., } 2016 \text {, } \\
138,9128-9136 .\end{array}$ \\
\hline
\end{tabular}

* data measured in $0.1 \mathrm{M} \mathrm{KOH}$ solution. 
Table S4. The overall water splitting properties of p-NFNR@Ni-Co-P compared with other non-precious metal-based overall water splitting catalysts in $1 \mathrm{M} \mathrm{KOH}$.

\begin{tabular}{|c|c|c|c|c|}
\hline \multirow{2}{*}{ Catalysts } & \multicolumn{2}{|c|}{$\eta_{10}(\mathrm{mV})$} & \multirow{2}{*}{$\begin{array}{c}\mathrm{E}(\mathrm{V}) \\
\text { @ } 10 \mathrm{~mA} \mathrm{~cm} \mathrm{~cm}^{-2}\end{array}$} & \multirow{2}{*}{ References } \\
\hline & HER & OER & & \\
\hline p-NFNR@Ni-Co-P & 125 & 272 & 1.62 & This work \\
\hline CoP NFs & 136 & 323 & 1.65 & $\begin{array}{c}\text { ACS Catal. } 2020,10,1,412- \\
419 .\end{array}$ \\
\hline Ce-NiFe-LDH & 147 & 175 & 1.59 & $\begin{array}{l}\text { Sustain. Energ. Fuels, } 2020, \\
4,312-323\end{array}$ \\
\hline $\mathrm{Ni}_{2} \mathrm{P} @ \mathrm{NSG}$ & 110 & 240 & 1.572 & $\begin{array}{l}\text { Chem. Mater., 2021, 33, 1, } \\
\text { 234-245 }\end{array}$ \\
\hline $\mathrm{Co}_{2} \mathrm{P} / \mathrm{CoNPC}$ & 130 & 326 & 1.64 & $\begin{array}{l}\text { Adv. Mater., 2020, 32, } \\
2003649 .\end{array}$ \\
\hline $\begin{array}{c}\text { Co-Fe } \\
\text { oxyphosphide MTs }\end{array}$ & 180 & 280 & 1.69 & Adv. Sci., 2019, 6, 1900576. \\
\hline $\mathrm{Co}_{0.6} \mathrm{Fe}_{0.4} \mathrm{P}-1.125$ & 133 & 298 & 1.57 & $\begin{array}{l}\text { Chem. Sci., 2019, 10, 464- } \\
474 .\end{array}$ \\
\hline $\begin{array}{c}\mathrm{Co}_{1}-\mathrm{Fe}_{1}-\mathrm{B}-\mathrm{P} \\
\text { nanochains }\end{array}$ & 173 & 225 & 1.68 & $\begin{array}{c}\text { Nanoscale, } 2019,11,7506- \\
7512 .\end{array}$ \\
\hline $\mathrm{CVN} / \mathrm{CC}$ & 118 & 263 & 1.64 & $\begin{array}{l}\text { Appl. Catal. B-Environ., } \\
\text { 2019, 241, 521-527. }\end{array}$ \\
\hline CoP@NPCSs & 115 & 350 & 1.643 & $\begin{array}{c}\text { ACS Appl. Mater. } \\
\text { Interfaces, } 2018,10,44201- \\
44208 .\end{array}$ \\
\hline CoP/NCNHP & 115 & 310 & 1.64 & $\begin{array}{c}\text { J. Am. Chem. Soc., } 2018 \text {, } \\
\text { 140, 7, 2610-2618. }\end{array}$ \\
\hline $\mathrm{CoSe}_{2} / \mathrm{MoSe}_{2}$ & 90 & 280 & 1.67 & $\begin{array}{l}\text { Energy Environ. Sci., 2016, } \\
9,478 .\end{array}$ \\
\hline $\mathrm{Ni}_{3} \mathrm{~S}_{2} / \mathrm{NF}$ & 223 & 260 & 1.76 & $\begin{array}{l}\text { J. Am. Chem. Soc., 2015, } \\
\text { 137, 14023. }\end{array}$ \\
\hline $\mathrm{NiFe}$ LDH/NF & 210 & 240 & 1.7 & $\begin{array}{c}\text { Science, } 2014,345,1593- \\
1596 .\end{array}$ \\
\hline $\mathrm{CP} / \mathrm{CNTs} / \mathrm{Co}-\mathrm{S}$ & 190 & 307 & 1.743 & ACS Nano, 2016, 10, 2342. \\
\hline $\mathrm{NiSe} / \mathrm{NF}$ & 96 & $270\left(\eta_{20}\right)$ & 1.63 & $\begin{array}{l}\text { Angew. Chem. Int. Ed. } \\
\text { 2015, 54, 9351-9355 }\end{array}$ \\
\hline $\mathrm{Co}_{3} \mathrm{O}_{4}$ nanocrystals & 380 & 320 & 1.91 & $\begin{array}{l}\text { Chem. Commun., 2015, 51, } \\
8066 .\end{array}$ \\
\hline Co-NC/CNT & 203 & 354 & 1.625 & $\begin{array}{c}\text { J. Mater. Chem. A, 2016, 4, } \\
\text { 16057-16063. }\end{array}$ \\
\hline $\mathrm{NiCo}_{2} \mathrm{~S}_{4} \mathrm{NS} / \mathrm{CC}$ & 181 & 240 & 1.66 & $\begin{array}{l}\text { ACS Sustainable Chem. } \\
\text { Eng., 2018, 6, 5011-5020. }\end{array}$ \\
\hline $\begin{array}{l}\mathrm{Fe}_{11.1 \%-} \mathrm{Ni}_{3} \mathrm{~S}_{2} / \mathrm{Ni} \\
\text { foam }\end{array}$ & 126 & $234\left(\eta_{50}\right)$ & 1.60 & $\begin{array}{l}\text { J. Mater. Chem. A, 2018,6, } \\
\text { 4346-4353. }\end{array}$ \\
\hline
\end{tabular}


Table S5. The Ni, Co, P and N content and electronic conductivity $(\sigma)$ in the sample of pNFNR@Ni-Co-P with different addition amount of PVP.

\begin{tabular}{|c|c|c|c|c|c|}
\hline & Ni & Co & P & N & $\begin{array}{c}\sigma \\
\left(* 10^{-2} \mathrm{~S} \mathrm{~cm}^{-1}\right)\end{array}$ \\
\hline p-NFNR@Ni-Co-P (PVP-1) & 8.9 & 9.6 & 8.2 & 3.04 & 5.2 \\
\hline p-NFNR@Ni-Co-P (PVP-0.5) & 5.4 & 6.2 & 5.8 & 2.13 & 4.8 \\
\hline p-NFNR@Ni-Co-P (PVP-1.5) & 9.2 & 10.5 & 9.7 & 4.25 & 4.6 \\
\hline
\end{tabular}




\section{References:}

1. Park, C.; Song, H. J.; Choi, H. C., The Critical Effect of Solvent Geometry on the Determination of Fullerene $\left(\mathrm{C}_{60}\right)$ Self-Assembly into Dot, Wire and Disk Structures. Chem. Commun. 2009, 32, 4803-4805.

2. Wang, L.; Liu, B.; Liu, D.; Yao, M.; Hou, Y.; Yu, S.; Cui, T.; Li, D.; Zou, G.; Iwasiewicz, A.; Sundqvist, B., Synthesis of Thin, Rectangular $\mathrm{C}_{60}$ Nanorods Using $\mathrm{m}$-Xylene as a Shape Controller. Adv. Mater. 2006, $18(14), 1883-1888$.

3. Rao, A. M.; Zhou, P.; Wang, K.-A.; Hager, G. T.; Holden, J. M.; Wang, Y.; Lee, W.-T.; Bi, X.-X.; Eklund, P. C.; Cornett, D. S.; Duncan, M. A.; Amster, I. J., Photoinduced Polymerization of Solid C 60 Films. Science 1993, 259 (5097), 955-957.

4. Geng, J.; Zhou, W.; Skelton, P.; Yue, W.; Kinloch, I. A.; Windle, A. H.; Johnson, B. F. G., Crystal Structure and Growth Mechanism of Unusually Long Fullerene (C60) Nanowires. J. Am. Chem. Soc. 2008, $130(8)$, 2527-2534.

5. Feng, Y.; Wang, X.; Huang, J.; Dong, P.; Ji, J.; Li, J.; Cao, L.; Feng, L.; Jin, P.; Wang, C., Decorating CoNi Layered Double Hydroxides Nanosheet Arrays with Fullerene Quantum Dot Anchored on Ni Foam for Efficient Electrocatalytic Water Splitting and Urea Electrolysis.

Chem. Eng. J. 2020, 390, 124525. 
6. Pan, Y.; Sun, K.; Liu, S.; Cao, X.; Wu, K.; Cheong, W.-C.; Chen, Z.; Wang, Y.; Li, Y.; Liu, Y.; Wang, D.; Peng, Q.; Chen, C.; Li, Y., Core-Shell ZIF-8@ZIF-67-Derived CoP Nanoparticle-Embedded N-Doped Carbon Nanotube Hollow Polyhedron for Efficient Overall Water Splitting. J. Am. Chem. Soc. 2018, 140 (7), 2610-2618.

7. Kang, Q.; Li, M.; Shi, J.; Lu, Q.; Gao, F., A Universal Strategy for Carbon-Supported Transition Metal Phosphides as High-Performance Bifunctional Electrocatalysts towards Efficient Overall Water Splitting. ACS Appl. Mater. Interfaces 2020, 12 (17), 19447-19456.

8. Liu, J.; Wang, Z.; David, J.; Llorca, J.; Li, J.; Yu, X.; Shavel, A.; Arbiol, J.; Meyns, M.; Cabot, A., Colloidal $\mathrm{Ni}_{2-\mathrm{x}} \mathrm{Co}_{\mathrm{x}} \mathrm{P}$ Nanocrystals for the Hydrogen Evolution Reaction. J. Mater. Chem. A 2018, 6(24), 11453-11462.

9. Xu, J.; Liu, T.; Li, J.; Li, B.; Liu, Y.; Zhang, B.; Xiong, D.; Amorim, I.; Li, W.; Liu, L., Boosting the Hydrogen Evolution Performance of Ruthenium Clusters Through Synergistic Coupling with Cobalt Phosphide. Energ. Environ. Sci. 2018, 11 (7), 1819-1827.

10. Wu, R.; Xiao, B.; Gao, Q.; Zheng, Y.-R.; Zheng, X.-S.; Zhu, J.-F.; Gao, M.-R.; Yu, S.-H., A Janus Nickel Cobalt Phosphide Catalyst for High-Efficiency Neutral-pH Water Splitting. Angew. Chem. Int. Ed. 2018, 57 (47), 15445-15449. 
11. Zhu, W.; Yue, Z.; Zhang, W.; Hu, N.; Luo, Z.; Ren, M.; Xu, Z.; Wei, Z.; Suo, Y.; Wang, J., Wet-Chemistry Topotactic Synthesis of Bimetallic Iron-Nickel Sulfide Nanoarrays: An Advanced and Versatile Catalyst for Energy Efficient Overall Water and Urea Electrolysis. $J$. Mater. Chem. A 2018, 6(10), 4346-4353.

12. Zhang, Y.; Shao, Q.; Long, S.; Huang, X., Cobalt-Molybdenum Nanosheet Arrays as Highly Efficient and Stable Earth-Abundant Electrocatalysts for Overall Water Splitting. Nano Energy 2018, 45, 448-455.

13. Jian, J.; Yuan, L.; Qi, H.; Sun, X.; Zhang, L.; Li, H.; Yuan, H.; Feng, S., Sn-Ni ${ }_{3} \mathrm{~S}_{2}$ Ultrathin Nanosheets as Efficient Bifunctional Water-Splitting Catalysts with a Large Current Density and Low Overpotential. ACS Appl. Mater. Interfaces 2018, 10 (47), 40568-40576.

14. Wang, G.; Chen, J.; Li, Y.; Jia, J.; Cai, P.; Wen, Z., Energy-Efficient Electrolytic Hydrogen Production Assisted by Coupling Urea Oxidation with A pH-Gradient Concentration Cell. Chem. Commun. 2018, 54 (21), 2603-2606. 